*ak RMIS View/Frint Document Cover Sheet tow

This document was retrieved from the Documentation and Records Manaqement (DRM) ISEARCH System. It is intended for Information only and may not be the most recent or updated version. Contact a Document Service Center (see Hanford Info for locations) if you need additional retrieval information.

Accession \#: D195067909

Document \#: SD-WM-OMM-024

Title/Desc:

SURFACE MOISTURE MEASUREMENT SYSTEM OMM

Pages: 64 


\begin{tabular}{|l|l|}
\hline DEC 191090 & 100 \\
\hline
\end{tabular}

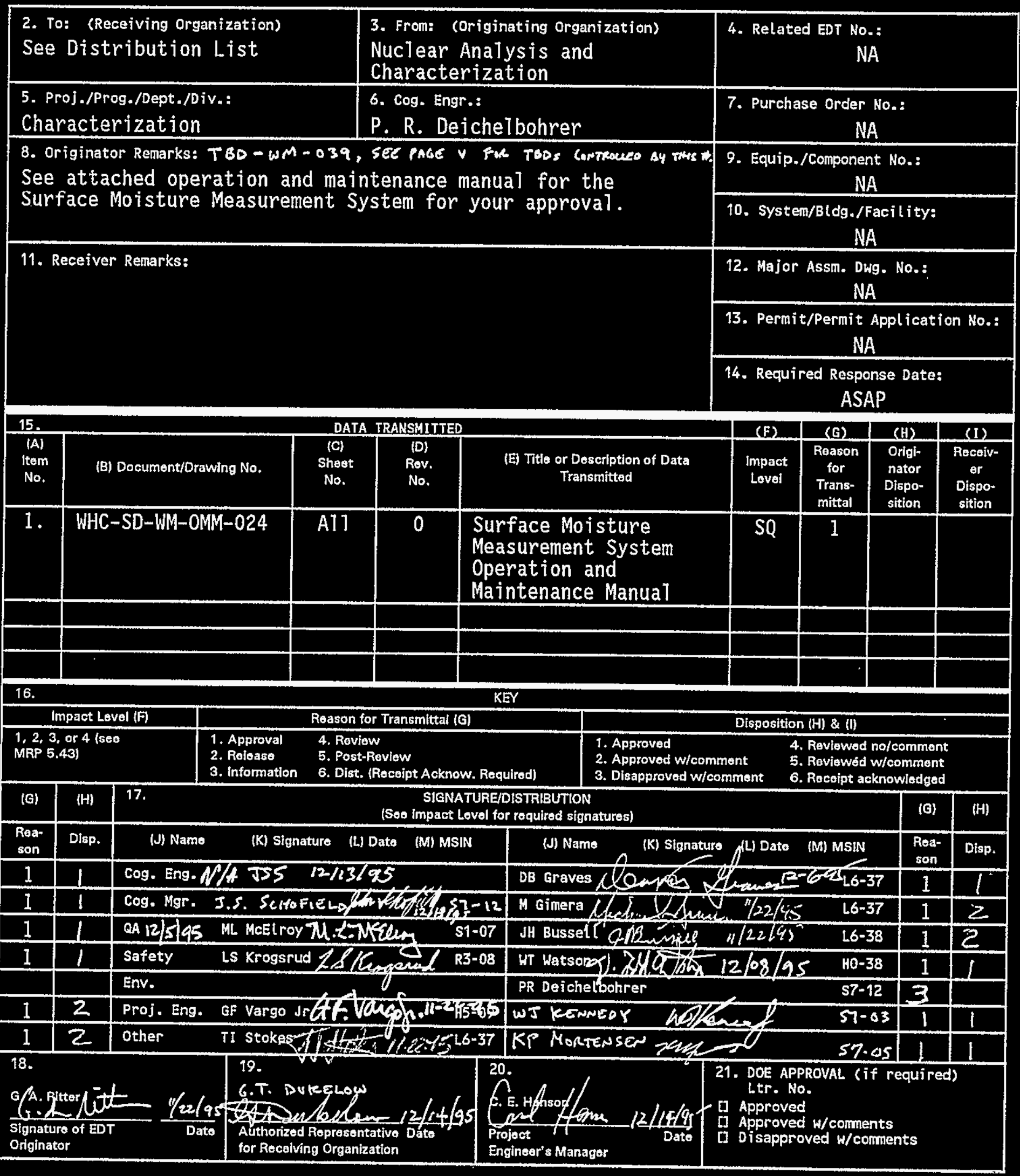

BD-7400-172-2 (07/91) GEF097 


\title{
Surface Moisture Measurement System Operation and Maintenance Manual
}

\author{
Glenn A. Ritter \\ Kathleen L. Pearce \\ Westinghouse Hanford Company, Richland, WA 99352 \\ U.S. Department of Energy Contract DE-AC06-87RL10930
}

Troy I. Stokes

HiLine Engineering and Fabrication

$\begin{array}{lll}\text { EDT/ECN: } & 611685 & \text { UC: } 706 \\ \text { Org Code: } & 8 M 720 & \text { Charge Code: } \\ \text { B\&R Code: } & \text { EW3120074 } & \text { Total Pages: } 61\end{array}$

Key Words: moisture measurement, neutron probe, Tiquid observation we]1, operating procedures, maintenance

Abstract: This operations and maintenance manual addresses deployment, equipment and field hazards, operating instructions, calibration verification, remova1, maintenance, and other pertinent information necessary to safely operate and store the Surface Moisture Measurement System (SMMS) and Liquid Observation Well Moisture Measurement System (LOWMMS). These systems were developed primarily in support of Tank Waste Remediation System (TWRS) Safety Programs for moisture measurement in organic and ferrocyanide watch 1ist tanks.

TRADEMARK DISCLAIMER. Reference herein to any specific commercial product, process, or service by trade name, trademark, manufacturer, or otherwise, does not necessarily constitute or imply its endorsement, recommendation, or favoring by the United states Government or any agency thereof or its contractors or subcontractors.

Printed in the United States of America. To obtain copies of this document, contact: WHC/BCS Document Control Services, P.0. BoX 1970, Hailstop H6-08, Rightandummo0352 ghona (509) 372-2420; Fax (509) 376-4989.
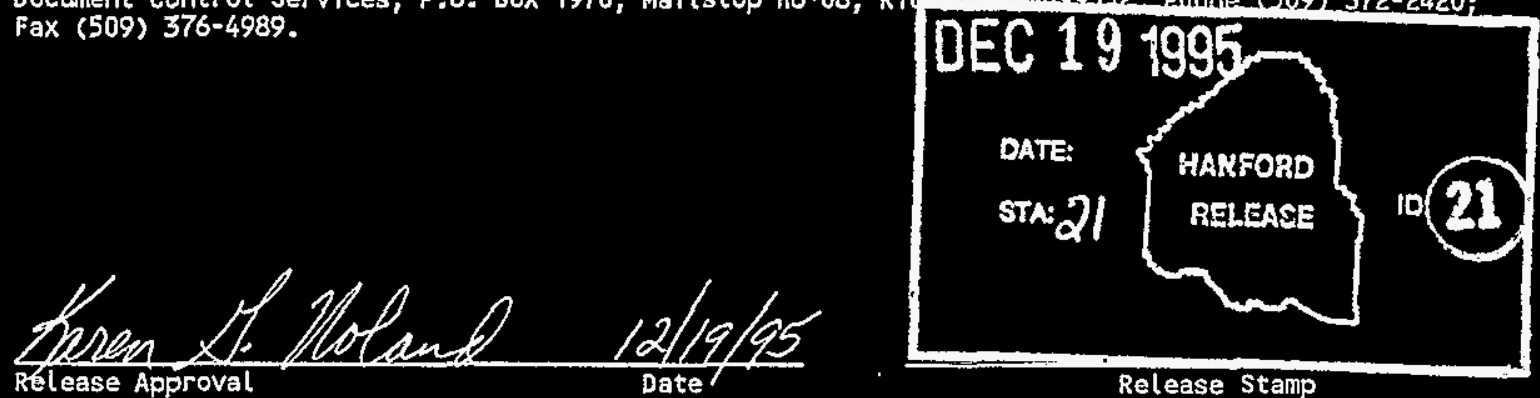

Approved for Public Release 
CONTENTS

1.0 GENERAL EQUIPMENT INFORMATION $\ldots \ldots \ldots \ldots$

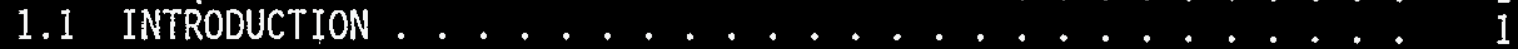

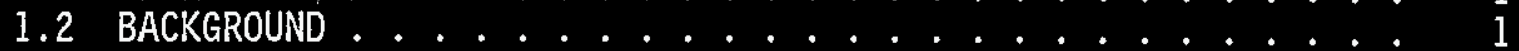

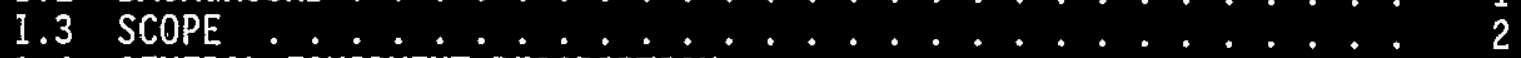

1.4 GENERAL EQUIPMENT DESCRIPTION..$\cdots 2$

1.5 EQUIPMENT, ACCESSORIES, AND DOCUMENTS SUPPLIED $\ldots \ldots . .5$

1.6 DOCUMENTATION REQUIRED TO FIELD OPERATE ........ 6

2.0 FUNCTION DESCRIPTION . . . . . . . . . . . . 6

2.1 SURFACE MOISTURE MEASUREMENT SYSTEM ......... 6

2.2 LIQUID OBSERVATION WELL MOISTURE MEASUREMENT SYSTEM $\cdots \cdots$

2.3 DATA ACQUISITION VAN ............... 8

3.0 GENERAL SAFETY PRECAUTIONS AND CONTROLS ........... 9

3.1 PERSONNEL PRECAUTIONS ..................... 9

3.2 EQUIPMENT PRECAUTIONS......... .10

3.3. ADMINISTRATIVE CONTROLS FOR THE SOURCE AND VEHICLE $: \ldots \ldots 10$

4.0 PREPARATION FOR DEPLOYMENT . . . . . . . . . . . . 14

4.1 INSTALLATION DRAWINGS ............................ 14

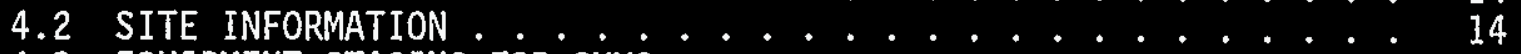

4.3 EQUIPMENT STAGING FOR SMMS $\therefore \ldots \ldots$

4.4 EQUIPMENT STAGING AND INSTALLATION FOR LOWMMS ...... 16

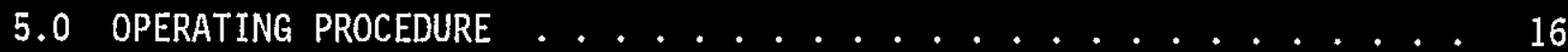

5.1 DAV STARTUP SEQUENCE ............... 16

5.2 SMMS OPERATING PROCEDURE $: \cdots \cdots \cdots$

5.3 LOWMMS OPERATING PROCEDURE .............. 30

5.4 PROBE CALIBRATION CHECK .................... 36

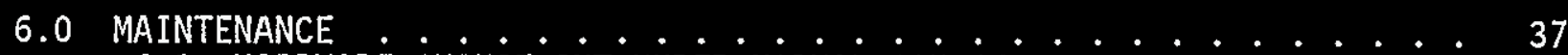

6.1 HARDWARE CHANGE-OUT UNDER NORMAL CONDITIONS $\cdots \cdots$

6.2 PREVENTATIVE MAINTENANCE .............. 37

7.0 TROUBLESHOOTING . . . . . . . . . . . . 38

7.1 LOSS OF POWER

7.2 COMPUTER SYSTEM FAILURE $\ldots \ldots . . \ldots 38$

7.3 COMPUTER SOFTWARE ERRORS ......................... 38

7.4 INSTRUMENT HARDWARE FAILURE .................. 39

8.0 RESPONSE TO ABNORMAL CONDITIONS ............. 39

8.1 GENERAL $\ldots \ldots \ldots \ldots \ldots$

8.2 SOFTWARE ALARMS $\ldots \ldots \ldots \ldots$

9.0 REFERENCES ......................... 40 


\section{LIST OF FIGURES}

1-1. Surface Moisture Measurement System . . . . . . . . . . . . 43

1-2. Liquid Observation We11 Moisture Measurement System . . . . . . 44

2-1. Layout of the Driver Side Cabinets in the DAV . . . . . . . 45

2-2. Layout of the Passenger Side Cabinets in the DAV . . . . . 46

$2-3$. Operator Control Console in the DAV . . . . . . . . . 47

2-4. SMMS Software Front Panel Display . . . . . . . . . . 48

2-5. LoWMMS Software Front Panel Display .......... 49

3-1. Combined Neutron and Gamma Dose from the SMMS Neutron Source . . 50

3-2. Combined Neutron and Gamma Dose from the LOWMMS Neutron Source . . 51

5 -1. Circuit Breaker Pane1 Layout . . . . . . . . . . 52

5-2. SMMS and LOWMMS Instrument Cable Connections .........553

5 -3. SMMS Source Transfer Cask Arrangement . . . . . . . . . 54

$5-4$. LowMMS Source Transfer Cask Arrangement. $\ldots \ldots$

$5-5$. SMMS Decontamination System Block Diagram . . . . . . . 56 


\section{LIST OF TERMS}

$\begin{array}{ll}\text { ALARA } & \text { as low as reasonably achievable } \\ \text { CO } & \text { carbon monoxide } \\ \text { DAV } & \text { Data Acquisition Van } \\ \text { DOT } & \text { U.S. Department of Transportation } \\ \text { ECN } & \text { engineering change notice } \\ \text { JCS } & \text { Job Control System } \\ \text { LOW } & \text { Tiquid observation wel1 } \\ \text { LOWMS } & \text { Liquid Observation We11 Moisture Measurement System } \\ \text { NEC } & \text { National Electrical Code } \\ \text { OMM } & \text { operations and maintenance manual } \\ \text { RSR } & \text { radioactive shipping record } \\ \text { SAIC } & \text { Science Applications International Corporation } \\ \text { SMMS } & \text { Surface Moisture Measurement System } \\ \text { TWRS } & \text { Tank Waste Remediation System } \\ \text { VCR } & \text { video cassette recorder } \\ \text { WHC } & \text { Westinghouse Hanford Company }\end{array}$




\section{LIST OF TBDS}

TBD-WM-039:

KBD- 2 Section 6.1.1 SMMS hardware change-out procedures . . . . . . 37

TER-2 Section 6.1 .2 LOWMM hardware change-out procedures . . . . 37

TDO-3 Figure 5-3. SMMS Source Transfer Cask Arrangement . . . . . 54

ABD-4 Figure 5-4. LOWMMS Source Transfer Cask Arrangement . . . . . 55 
WHC-SD-WM-OMM-024 REV 0

\author{
SURFACE MOISTURE MEASUREMENT SYSTEM \\ OPERATION AND MAINTENANCE MANUAL
}

\title{
1.0 GENERAL EQUIPMENT INFORMATION
}

\subsection{INTRODUCTION}

The purpose of this manual is to provide detailed operating instructions for the Surface Moisture Measurement System (SMMS). In addition, operating instructions for the Liquid Observation We11 Moisture Measurement system (LOWMMS) are included. These systems were developed primarily in support of Tank Waste Remediation System (TWRS) Safety Programs for moisture measurement in organic and ferrocyanide watch 1 ist tanks.

\subsection{BACKGROUND}

Radioactive wastes from defense operations have accumulated in underground waste storage tanks at the Hanford Site since the $1940^{\prime} \mathrm{s}$. Potential fuels, in the form of ferrocyanide and various organic compounds, may be present in many of these tanks. Safety concerns have risen based on the possibility of condensed phase chemical reactions propagating into undesirable consequences.

Analyses and experiments indicate that the reaction propagation and possibly its initiation may be precluded by the presence of sufficient concentration of moisture in the waste. If sufficient moisture is present in a fuel-containing waste boundary between an initiated reaction and a dry stoichiometric mixture of fuel and oxidizer, modeling predicts that the water will absorb the energy released from the reaction so that it will not propagate through the waste boundary (Meacham et a]. 1995). Because the credible reaction initiators would be expected to occur at the waste surface, sufficient moisture concentration in the top layers of waste would, under current safety guidelines, provide evidence that the tank waste is in a stable and safe form for continued storage.

The SMMS was developed by Westinghouse Hanford Company (WHC), Science Applications International Corporation (SAIC), ICF Kaiser, and HiLine Engineering \& Fabrication Inc. to determine the moisture concentration in the upper layers of the waste surface. Waste moisture concentration profiles for tanks that contain liquid observation wel1s (LOW) will be obtained with the LOWMMS, which is controlled using the same data acquisition and controt system as the SMMS. The LOWMMS will provide a second method of measuring the waste moisture concentration. The LOWMMS moisture measurements of the waste surface immediately surrounding the LOW will help confirm the measured surface moisture obtained with the SMMS. 


\subsection{SCOPE}

This operations and maintenance manual (OMM) addresses deployment, equipment and field hazards, operating instructions, calibration verification, removal, maintenance, and other pertinent information necessary to safely operate and store the SMMS and LOWMMS.

This OMM also includes radiation protection requirements associated with usage of the neutron sources, which are part of the SMMS and LOWMMS probes. The radiation protection requirements of this OMM address personne] qual ifications and responsibilities, dosimetry requirements, source handling equipment, and required documentation for use of the neutron sources. These requirements are specified in accordance with WHC-CM-1-6, WHC Radiological Contro7 Manua7.

Final decontamination and decommissioning of these systems are not covered in this document.

These systems shall only be operated by Characterization Equipment Development (CED) personnel or CED's designated personnel. Operations will provide personnel to instal1 and remove the SMMS deployment device from a tank riser and provide general field assistance as required to operate the systems.

\subsection{GENERAL EQUIPMENT DESCRIPTION}

Refer to WHC-SD-WM-SDD-066*, Surface Moisture Measurement System Design Description (Stokes 1996), for a more detailed description of the SMMS.

\subsubsection{Surface Moisture Measurement System}

The SMMS is shown in Figure 1.1 and consists of the following components:

- A sensor (surface neutron probe) that consists of a neutron source, three neutron detectors, high voltage power transformer, temperature sensors, and supporting electronics.

- A deployment device that consists of a support mast, an arm, and winch systems to lower and raise the arm and probe.

- A data acquisition van (DAV) that is equipped with the following:

- Control console with flat panel computer system

- Video monitor and video cassette recorder (VCR)

- Generator to power the batteries

- Batteries to power the equipment

- Electrical distribution system

*To be issued 
WHC-SD-WM-OMM-024 REV 0

- Data processing electronics

- Electric-powered cable reel with remote controller (for LOWMMS on1y)

- Rotating boom with guide pulleys (for LOWMS only).

- A decontamination system that consists of a high pressure spray ring that mounts on the riser, a gas-powered pressure washer, a gas-powered feed pump, a water tank, totalizers, and various hoses and fittings.

The surface sensor package is a neutron probe that infers the moisture content of the top layers of the waste surface by measuring the neutron moderating properties. These properties are a strong function of the hydrogen concentration of the waste which is related primarily to the water content. The probe obtains penetrating moisture data up to a maximum depth of about $16 \mathrm{~cm}$ for very dry waste. The penetration depth decreases for higher moisture waste. Three moisture indications are recorded: one near the surface (about $5 \mathrm{~cm}$ for $15 \mathrm{wt} \%$ moisture), at the mid-point (about $7 \mathrm{~cm}$ for $15 \mathrm{wt} \%$ moisture), and at the maximum depth (about $10 \mathrm{~cm}$ for $15 \mathrm{wt} \%$ moisture) are recorded. The probe measures moisture in the range of 0 to 40 percent by weight of water. The SMMS was designed to be operated in a National Electric Code (NEC) hazardous area classified as Class I, Division 1, Group B. The neutron source used with the SMMS probe is an encapsulated 16- $\mu \mathrm{g}, 9.1 \mathrm{mCi}$, californium-252 $\left({ }^{252} \mathrm{Cf}\right)$ source.

The deployment device consists of a vertical support mast with a rotating arm, which can be vertically rotated through a controlled angle to position the probe at a radius between 0 and $2 \mathrm{~m}(6 \mathrm{ft})$ from the riser centerline. A deployment cable, guided over the arm, mechanically lowers the probe to the waste surface. The arm also houses an inclinometer and associated cable.

The deployment device, which is approximately $590 \mathrm{~kg}$ (1300 7b), will be installed in a 4-inch or larger waste tank riser using a crane. The deployment device interfaces with a DAV that controls the sensor operation and records pertinent data. The DAV is a standalone system and connections to existing tank farms utilities are not required. Electrical power for the SMMS components is provided from one of. three sources: the DAV's batteries, the DAV's generator, or a site service receptacle. Interconnecting cables will be placed above ground and routed between the van and the deployment device. The SMMS and supporting equipment are portable and only temporarily installed in a waste tank. The deployment device will be packaged in a weather-tight container for storage and transportation. The SMMS neutron source will be transported in a U.S. Department of Transportation (DOT) 7A Type A shipping container located inside of the DAV. The source will be stored in a locked, shielded location when not in use.

During measurement sequences, the arm will be raised to a specified angle and the deployment device will rotated to a specified orientation. The probe then will be mechanically lowered until it makes contact with the waste surface. The probe is not intended to penetrate the waste. A separate 
WHC-SD-WM-OMM-024 REV 0

in-tank camera installed in an adjacent riser will provide visual feedback for a1] in-tank operations including probe deployment and placement. This in-tank camera is mandatory for successful SMMS operation. A video monitor will be located next to the riser to help the operator position the probe. Approximately 15 percent of the surface area within a $4 \mathrm{~m}$ (12 ft) diameter region will be scanned per the tank-specific test plan. Each probe measurement interrogates a region of approximately $40 \mathrm{~cm}$ (16 in.) in diameter. Measurements will be made in such a way as to avoid large gaps in the data. The system allows any measurement to be repeated and allows for a higher spatial resolution to fill in missing gaps.

\subsubsection{Liquid Observation We11 Moisture Measurement System}

The LOWMMS, which is shown in Figure 1.2, consists of the following components :

- Thermal dual detector neutron probe

- Epithermal dual detector neutron probe

- A spider assembly that mounts to the top of a LOW to guide the probe down the LOW

- A data acquisition van (same as above for the SMMS).

The LOWs are located within selected single shell waste tanks and were installed through risers in the top of the tanks. They are essentially long, fiberglass, 7.9-cm-inside-diameter tubes that extend from the top of a riser to the bottom of a waste tank. The LOWs are drywe7ls; that is, they are closed on the bottom and sealed from the tank waste environment. Each probe will be lowered into the LOW to determine the moisture concentration in the waste immediately surrounding the LOW. The data from these measurements will provide a vertical profile of the waste tank moisture concentration. Some LOWs are known to have failed structurally. These LOWs will not be scanned.

Raising and lowering each probe within the LOW is controlled by actuating the drawworks that are mounted to the front of the DAV. The drawworks consist of an electric-powered cable reel and rotating boom. A LOW fixture (spider assembly) is mounted to the top flange of the LOW and is equipped with pulleys to guide the probe down the LOW. The spider assembly also has an electronic encoder to measure how far the probe has been lowered and a proximity sensor to detect the start and stop positions for the scan. The Lows will be barcoded so that they can be scanned with the barcode reader and the computer software will automatically load the appropriate data for performing the scan. The neutron source used with the LOWMMS probes is a doubly encapsulated $1.7 \mathrm{Ci}$ americium/beryl1ium $\left({ }^{241} \mathrm{Am} / \mathrm{Be}\right)$ source.

During measurement sequences, the probe is lowered to the bottom of the LOW. The probe then ascends the LOW and stops at specified intervals white the computer system records data. The distance between measurements and the data collection period (count time) can be specified or default values will be 
used. The data received into the computer then are transferred to a storage disk after the scan has been completed.

\subsection{EQUIPMENT, ACCESSORIES, AND DOCUMENTS SUPPLIED}

A full 1ist. of documentation associated with the SMMS can be found in WHC-SD-WM-SDD-066*

\subsubsection{Surface Moisture Measurement System}

Drawing H-14-100458*, Surface Moisture Monitoring System Installation Assembly (WHC 1996a), identifies all the components required to install, operate, and remove the SMMS from a tank riser.

The primary SMMS component drawings referenced on the installation drawing are listed below:

- H-14-100459* Surface Moisture Monitoring System Deployment Enclosure (WHC 1996b)

H-14-100460*, Surface Moisture Monitoring System Deployment Arm (WHC 1996C)

H-14-100461* Surface Moisture Monitoring System Neutron Detector Assemb7y (WHC 1996d)

H-14-100462* Surface Moisture Monitoring System Decon System Assemb7y (WHC 1996e)

1. H-14-100463*, Surface Moisture Monitoring System Impact Limiter Assembly (WHC 1996f)

, H-14-100464:, Surface Moisture Monitoring System Vehicle Modifications (WHC $1996 \mathrm{~g}$ )

H-14-100477* Surface Moisture Monitoring System Cable Assemblies (WHC 1996h)

\subsubsection{Liquid Observation Hel1 Moisture Measurement System}

Drawing H-14-100465; LOW Probe Delivery System Assembly (WHC 1996i), identifies the components required to instal1, operate, and remove the LowMS from a LOW.

The primary LOWMMS component drawing referenced on the assembiy drawing is 1 isted below:

\section{H-14-100464*, Surface Moisture Monitoring System Vehicle Modifications}

*To be issued. 


\subsection{DOCUMENTATION REQUIRED TO FIELD OPERATE}

The following documents must be used in conjunction with this OMM for installation, operation, and removal of the SMMS and the LOWMMS in any appication:

Job control system (JCS) work packages to control installation, removal, and troubleshooting. The work package also includes the critical $1 \mathrm{jft}$ procedure and incorporates controls in USQ TF-95-0089, Surface Moisture Monitoring of Hanford Tank Waste by Neutron Activation

Tank-specific test $p$ lan and procedures.

The JCS work package wil1 refer to the engineering approved test $\mathrm{p} 1 \mathrm{an}$, test procedures, OMM, or other documentation for operating these systems and performing the moisture measurement tests. The test plan and test procedures provide the tank-specific information for performing moisture measurement testing, such as data points required (from statistical considerations) and probe placement guidelines. The test procedures will reference this oMm for operating the equipment.

\subsection{FUNCTION DESCRIPTION}

\subsection{SURFACE MOISTURE MEASUREWENT SYSTEM}

The following sections identify drawings and other documentation that describe the function of the SMMS.

\subsubsection{Overa11 B7ock Diagram}

H-14-100467, Surface Moisture Measurement System Block Diagram (WHC 1996j).

\subsubsection{Design Media}

' H-14-100457*, Surface Moisture Measurement System Drawing Tree (WHC 1996k)

r H-14-100469* Operator Control Enclosure Surface Moisture Measurement System Wiring (WHC 19961)

- H-14-100471* Driver Side Electronics Enclosure Surface Mojsture Measurement System Wiring (WHC 1996m)

( H-14-100473* Passenger Side Electronics Surface Moisture Measurement System Wiring (WHC 1996n)

*To be issued. 
- H-14-100485*, Surface Moisture Measurement System Deployment Enclosure Wiring (WHC 19960)

- H-14-100552*, SMMS Source Hand7ing Too7 (WHC 1996p)

- H-14-100554 SMMS Source Transfer Cask Arrangement (WHC 1996q)

- H-14-100555, SMMS Long Hand7ed Tongs (WHC 1996r)

- H-14-100557* SMMS Ca7ibration Fixture \#1 (WHC 1996q)

- H-14-100558, SMMS Calibration Fixture \#2 (WHC 1996t)

\title{
2.1.3 Simptified Schematic Diagram
}

H-14-100474, Surface Moisture Measurement System Elementary Di agram (WHC 1996u)

\subsubsection{Vendor Data}

\author{
Vendor information file, VI 22719
}

\subsection{LIQUID OBSERVATION WELL MOISTURE MEASUREMENT SYSTEM}

\subsubsection{Overa11 Block Diagram}

H-14-100467* Surface Moisture Measurement System Block Diagram (includes LOWMMS)

\subsubsection{Design Media}

H-14-100294, Neutron Moisture Probe Source Hand7ing Too 7 (WHC 1995)

H-14-100486* Liquid Observation We7l Deployment Device Wiring Diagram (WHC 1996v)

H-14-100556; LOWMMS Source Transfer Cask Arrangement (WHC 1996W)

H-14-100559; LOWMMS Calibration Fixture \#I (WHC 1996x)

H-14-100560*, LOWMMS Calibration Fixture \#2 (WHC 1996y)

\subsubsection{Simplified Schematic Diagram}

H-14-100474: Surface Moisture Measurement System Elementary Diagram (includes LOWMMS)

*To be issued 


\subsubsection{Vendor Data}

- Vendor information file, VI 22719

See WHC-SD-WM-SDD-066 for detailed information regarding these systems including relevant design information, calculations, and safety equipment Tist.

\subsection{DATA ACQUISITION VAN}

The primary function of the DAV is to house and supply power to the computer system and electronics that $l 0 g$ and interpret probe data in real-time mode for both the SMMS and LOWMMS. The DAV's data acquisition and control system consists of a PC-based computer system with an industrial flat panel display, a multiple buffer multichannel analyzer, and support electronics (such as amplifiers, generator, wiring). The instrumentation is capable of nuclear pulse counting with discrimination while monitoring analog signal quality. The data acquisition system processes pulse rates (pulse height analysis and count data) up to 20,000 counts per second (cps) from each of the detectors. The SMMS has three detectors in the probe and the LOWMMS has two detectors in each of the two probes. Data is archived on a hard drive and transferable to floppy disks, as required.

Figures 2.1 through 2.3 are illustrations of the system instrumentation and power control units with in the van. Figure 2.1 shows the layout of the driver side cabinets and Figure 2.2 shows the layout of the passenger side cabinets in the DAV. The control console that was installed in place of the van $^{1} s$ passenger side front seat is shown in Figure 2.3.

\subsubsection{Operator Interface}

The LabVIEW] software uses a graphical user interface for ease of operation. Operator input is achieved with a capacitive touch screen. The screen implements both system mouse and keyboard functions at the touch of a finger.

\subsubsection{Software and Data Storage}

The SMMS and LOWMMS software are stored on the computer's hard disk drive. Data files may be retrieved from the hard drive with a $31 / 2-i n$. diskette or with a Syquest 135 MB cartridge by syquest Inc. At the end of the day, the data are downloaded and given to engineering for post processing.

\subsubsection{Front Panel Displays}

2.3.3.1 Surface Moisture Measurement System. Figure 2.4 shows the SMMS front pane1 (labeled "SMMS.VI"). When the LabVIEW program is running, the TAKE MEASUREMENT icon lets the operator control data acquisition from the probe.

*To be issued.

TLabVIEW is a trademark of National Instruments Corporation, Austin, TX. 
The probe position is displayed along with the detector responses and moisture concentrations. Additional information on this front pane1 display may be found in WHC-SD-WM-CSDD-017*, Software Design Description for Surface Moisture Monitor (Gimera 1996).

\subsubsection{Liquid Observation We11 Moisture Measurement System. Figure 2.5} shows the LOWMMS front panel (1abeled "LOWMMS.VI"). The LOWMMS software displays two panels, the first allows the operator to input the LOWMMS barcode or scan the barcode with a bar code reader. The second panel displays graphical representations of the detector response (count rate) and vertical position of the probe in the LOW. A START/STOP icon on the front pane1 is used to start or stop a scan. Once started, the program can be aborted at any time by pressing the STOP icon. An OPTIONS icon brings up another screen that allows the operator to make changes to the sampling parameters. These parameters are the length of each of four regions, the distance between scans for each region, and the duration of the scan for each region. A video camera is not used with LOWMMS operation. Additional information on the displays may be found in WHC-SD-WM-CSDD-018* Software Design Description for LOW Moisture Monitor (Gimera 1996a).

\subsection{GENERAL SAFETY PRECAUTIONS AND CONTROLS}

The following sections provide general safety precautions and controls to be followed when installing, operating, and transporting the SMMS and LOWMMS. The tank farm work plan and/or work package will provide tank specific controls that must be followed in addition to those given below.

\subsection{PERSONNEL PRECAUTIONS}

3.1.1 In case of fire or other emergency in the van, all power shall be secured by moving circuit breaker $\mathrm{CB}-1$ to the OFF position (the main circuit breaker Tocated on the power distribution pane1, see Figure 5.1).

3.1.2 A carbon monoxide (CO) monitor is located in the DAV. If the CO monitor warning signal occurs, turn off the van engine, exit the van, and ventilate the van. Wait for a minimum of 5 minutes for the co to dissipate. The CO monitor warning signal will automatically stop and reset when the unsafe co level no longer exists.

3.1.3 Exhaust piping becomes hot during operation and remains hot for a while after stopping an engine (e.g., van, generator, decon pumps). Be careful not to touch a muffler while it is hot.

3.1.4 The SMMS deployment device and probe may become contaminated (radiologically and chemically). Appropriate controls in accordance with HSRCM-1, Hanford Site Radiological Control Manual, are to be exercised when removing and storing the system.

*To be issued 
3.1.5 The cables routed from the van to the SMMS deployment device equipment present a personnel trip/fall hazard. The cables shall be isolated by barricades to the extent possible to alleviate the trip hazards.

3.1.6 The neutron probe uses a neutron source that will contribute to personnel exposures. Handling procedures and controls specified in Section 3.3 shall be followed.

\subsection{EQUIPMENT PRECAUTIONS}

3.2.1 Lifting of the SMMS deployment device is a "critical 1 ift" according to USQ TF-95-0089 and a 17 precautions addressed in DOE-RL-92-36, Hanford Site Hoisting and Rigging Manual, and the site-specific procedure must be followed.

3.2.2 The SMMS deployment device must be inserted into the riser using a crane for support and centering. An impact-limiting device will be temporarily installed on the riser or severe riser damage could result if the device was dropped.

3.2.3 The DAV may need to be located on top of the tank dome. Tank dome loading must be checked to verify that 1 imits are not exceeded.

3.2.4 Supply power to a subsystem must be OFF when connecting or disconnecting any electrical equipment or cables to that subsystem.

3.2.5 Failure to hook up or remove the power and interconnecting cables in the sequence prescribed in this manual could result in generation of unacceptable equipment voltages and in electrical arcing or sparking.

3.2.6 The SMMS deployment device could be bent if not supported and/or 1ifted correctly when in the horizontal position.

3.2.7 The generator is a potential source of electrical shock if misused. Do not expose the generator to moisture, rain, or snow. Do not operate the generator if it is wet, and do not operate it with wet hands.

3.2.8 The exhaust systems get hot enough to ignite some materials. Keep the generator at least $1 \mathrm{~m}$ away from buildings and other equipment during operation. Do not enclose the generator in any structure and keep flammable materials away from the exhausts. Refer to the specific operation manual (e.g., generator, feed pump, high pressure pump) for operating and refueling precautions.

\subsection{ADMINISTRATIVE CONTROLS FOR THE SOURCE AND VEHICLE}

\subsubsection{Personnel Responsibilities}

3.3.1.1 Source Custodian. The source custodian must have current training as a source custodian as required by WHC policies. The required training for custodians of californium or americium neutron sources is documented in WHC- 
IP-1019, Material Control and Accountability P7an, and in WHC-SD-QAPP-001, Quality Assurance Program P7an for Source Contro7. Radiological worker training, as required by the RWP, is described in WHC-CM-1-6. The source custodian is responsible for the following:

- Ensuring that the neutron sources used with the SMMS and LOWMMS probes are used and maintained in accordance with WHC-CM-1-6

- Ensuring that this OMM and the radiation work permit (RWP) are current and available during any use of the SMMS and LOWMMS

- Acting as the principle point of contact concerning source use, maintenance, or documentation

- Arranging for source shipments that meet DOT and WHC shipping regulations

- Immediately securing the source and work area if any condition is expected to exist that may affect personnel safety. Management and Radiation Control will be notified immediately if this situation arises

- Ensuring that personnel exposures are kept as low as reasonably achievable (ALARA) and below WHC administrative 7 imits.

3.3.1.2 Radiation Control. Radiation Control is responsible for the following:

- Reviewing and approving this OMM

- Developing RWPs for use of the neutron sources

- Providing personnel for sealed source leak testing every 6 months

- Providing trained and qualified personnel to perform the required radiation surveys during SMMS and LOWMMS operation.

\subsubsection{Transportation of the Neutron Source}

The neutron sources require special handling procedures commensurate with the radiation exposure potential. The neutron source used with the SMMS probe is an encapsulated $16-\mu \mathrm{g}, 9.1 \mathrm{mC} i,{ }^{252} \mathrm{Cf}$ source. The neutron source used with the LOWMMS probes is a doubly encapsulated $1.7 \mathrm{Ci}{ }^{241} \mathrm{Am} / \mathrm{Be}$ source. Shipping of the source requires the completion of a routine Radioactive Shipping Record (RSR) and an approved transporter with the proper dosimetry to drive the DAV. The transportation of the source shall be in accordance with WHC-CM-2-14, Hazardous Material Packaging and Shipping, WHC-SD-TP-DAP-008, Documentation and Analysis for Packaging for Surface Moisture $7 A$ Containers (Clements 1996), and WHC-IP-0972, Rev. 1, Source. Movement Procedure, which 
contains specific transportation and handling procedures for the SMMS and LOWMMS neutron sources. WHC-CM-2-14 incorporates appropriate DOT regulations. The primary administrative controls from these documents are as follows.

- The vehicle transporting the sources shall be labelled and placarded as specified by DOT regulations, as given in WHC-CM-2-14.

NOTE: The only material authorized for transport in the Frontier Technology Corporation Model 50240 shipping containers are the Gammatron Inc. $N-148^{241} \mathrm{Am} / \mathrm{Be}$ and Frontier Technology Corporation FTC-CF-690 ${ }^{252}$ Cf neutron sources, certified as special form by Certificate of Compliance USA/0331/S Revision 3 and USA/0367/S Revision 4, respectively. The maximum radioactive content shall be $4 \mathrm{Ci}$ of ${ }^{241} \mathrm{Am} / \mathrm{Be}$ and $11 \mathrm{mCi}$ of ${ }^{252} \mathrm{Cf}$. Exceeding this 7 imit will exceed the shielding capacity of the containers.

- The source cask shal1 not be used at temperatures below $-40{ }^{\circ} \mathrm{C}$ $\left(-40^{\circ} \mathrm{F}\right)$ and above $54{ }^{\circ} \mathrm{C}\left(130^{\circ} \mathrm{F}\right)$.

- The DAV shall not be moved until the neutron source is completely secured inside the source transfer cask.

- When carrying a neutron source the DAV shall come to a complete stop before proceeding across any railroad crossings that do not have automatic barriers and warning 1 ights.

- Maximum vehicle speed inside the 200 East or 200 West area is $56 \mathrm{~km} / \mathrm{h}(35 \mathrm{mph})$. Vehicle speed shall not exceed posted speed Timits. Maximum vehicle speed inside the tank farm is $8 \mathrm{~km} / \mathrm{h}$ (5 mph).

- Occupants of the DAV shall be aware of radiation hazards associated with spending long periods of time in the van while either neutron source is stored in its cask and shall be trained as radiological workers.

- Many tank farm road surfaces are unimproved; road surfaces may be slick during rain or snow conditions or visibility may be reduced because of wind and dust conditions. EXTREME CAUTION must be used at ALL TIMES when operating vehicles on these roadways.

\subsubsection{Radiation Work Permit}

Radiation Control shall generate an approved RWP for the use of the radioactive sources used with the SMMS and LOWMMS. AT1 use of a radioactive neutron source will require a current RWP. Al] personne] sha11 read and understand all provisions of the RWP associated with the use of neutron sources. The RWP Acknowledgement sheet must be signed by each individual, indicating that they have read and understand the applicable RWP. The RWP will specify the radiological worker training required for all personnel involved with the use of the neutron source. 


\subsubsection{Dosimetry Requirements}

A11 personnel associated with or observing the use of the SMMS and LOWMMS probes inside the radiation area sha71 wear a Hanford multipurpose dosimeter.

\subsubsection{Handling of the Neutron Sources}

The approximate dose rate from the SMMS ${ }^{252} \mathrm{Cf}$ source at a distance of $\frac{1}{25} \mathrm{~m}(3 \mathrm{ft})$ is $30 \mathrm{mrem} / \mathrm{h}$ at the date of this writing. The strength of the ${ }^{252}$ Cf source will degrade approximately 2 to 3 percent each month because of the relatively short half-life of ${ }^{252} \mathrm{C} f$. Figure 3.1 shows the combined neutron and gamma dose rate from the ${ }^{252} \mathrm{Cf}$ source as a function of the distance from the source at the date of this writing. The approximate dose rate from the LOWMS ${ }^{241} \mathrm{Am} / \mathrm{Be}$ source at a distance of $1 \mathrm{~m}(3 \mathrm{ft})$ is $6 \mathrm{mrem} / \mathrm{h}$. Figure 3.2 shows the combined neutron and gamma dose rate from the ${ }^{241} \mathrm{Am} / \mathrm{Be}$ source as a function of the distance from the source. Special tools are provided to eliminate physical contact with the sources $(\mathrm{H}-14-100552 *$ and H-14-100294).

A neutron source shall NOT be left unattended when not in use, unless secured in the casks and stored in an approved area, or safely installed inside a tank.

\subsubsection{Inspection and Maintenance of the Neutron Sources}

The source custodian or his designee(s) shall visually check each source for defects in the outer source encapsulation before its use on any day. Defective or suspected defective source encapsulation shall not be used and shall be tagged out of service. If, during the use of the source, personnel have reason to believe that the outer encapsulation may have been breached, an emergency situation will be declared until the capsulation integrity is verified by Radiation Control. In the event of a source handling drop, an integrity test would be obtained from Radiation Control prior to further use.

A source inventory and integrity test must be performed every six months. DO NOT use a source if the Radioactive Source Inventory and Integrity Test Record has expired. However, for the source used with the SMMS probe (FTC-CF-690 ${ }^{252} \mathrm{Cf}$ neutron source), this test is only required prior to in-tank deployment. This test cannot be performed on a contaminated source. After the SMMS has been deployed in a waste tank, the source will be assumed to be contaminated, and must be handled as if it were contaminated.

\footnotetext{
*To be issued
} 


\subsection{PREPARATION FOR DEPLOYMENT}

\subsection{INSTALLATION DRAWINGS}

The following installation drawings are used for installing the SMMS and LOWMS, respectively:

\section{H-14-100458* Surface Moisture Monitoring System Installation Assemb7y}

\section{H-14-100465* LOW Probe De7ivery System Assemb7y}

These are generic installation drawings providing installation information applicable to any tank farm (H-14-100465 is only applicable to tanks with a LOW). Site-specific installation information is provided in the tank farm work package and any accompanying temporary engineering change notices (ECNS) against site drawings.

\subsection{SITE INFORMATION}

\subsubsection{Equipment Location}

Firm, level ground is required for placement of the DAV. The distance between the van and the SMMS deployment device shall be no greater than $15 \mathrm{~m}$ $(50 \mathrm{ft})$. For deployment of the LOWMMS, the van sha11 be no more than $15 \mathrm{~m}$ $(50 \mathrm{ft}$ ) from the LOW. Site location of the SMMS and LOWMMS may be in a radiation area. The required documentation as specified in Section 1.6 must be prepared and adhered to before installation of the moisture measurement systems.

\subsubsection{Electrical Power}

The DAV has a 120 VAC power generation system with a battery-backed uninterruptible power supply to stabilize and provide uninterrupted power. The DAV can operate for at least 6 hours on battery power. If electrical power is to be used instead of the generator or batteries, the DAV will require a $120 \mathrm{VAC}, 20 \mathrm{~A}$, standard three prong receptacle.

\subsubsection{Tools and Materials}

Special tools and materials required for installation of the SMMS deployment device onto any 4-inch (or Targer) riser are 7 isted on drawing H-14-100458. For deployment of the LOWMS probes in a LOW, special tools are listed on $\mathrm{H}-14-100465$. Any tools and materials not listed on the installation drawings are specified in the tank farm work package or installation work plan.

A separate camera system will be installed in an adjacent riser to show the in-tank view for SMMS probe deployment and placement on the waste surface. 
A video monitor will be located by the riser to provide feedback to the operator controlling the winches. The in-tank camera video signal will also be routed to a VCR and video monitor located in the DAV.

\subsection{EQUIPMENT STAGING FOR SHMS}

\subsubsection{Data Acquisition Van} ground.

Park the van within $15 \mathrm{~m}(50 \mathrm{ft})$ of the tank riser on firm, leve1

\subsubsection{Riser Containment} package.

Set up containment on the riser as specified in the tank farm work

\subsubsection{In-tank Camera}

Install camera in the nearest available adjacent riser as specified in the tank farm work package.

\subsubsection{Decontamination System}

4.3.4.1 Install the decontamination spool piece onto the tank riser per H-14-100458* or other relevant installation drawing for the particular tank being scanned.

4.3.4.2 Verify that a rubber wiper is installed on top of the decontamination spool piece.

4.3.4.3 Install impact limiters as specified in $\mathrm{H}-14-100458$.

\subsubsection{Deployment Device}

The deployment device will be transported from tank to tank in an approved transport container (WHC 1996z) in accordance with WHC-SD-TP-SEP-043*, Safety Evaluation for Packaging (SEP) Surface Moisture Equipment (Clements 1996a). After the deployment device is removed from the container, spacers in the mast and arm may need to be installed or removed as specified in the work package for the particular tank to be scanned. Detailed lifting procedures are provided in the critical lift procedure, this section provides general information for reference only.

\subsubsection{Attach the crane to the hoist rings at the top of the deployment} device with the appropriate rigging.

4.3.5.2 Remove and store the 8 flange nuts and bolts securing the deployment device to the storage container. 
4.3.5.3 Slide the deployment device out of the container, attaching one midpoint lifting clamp to the deployment device as specified in the critical lift procedure. Attach crane boom to the midpoint clamp to continue removal.

4.3.5.4 Lift and set the deployment device onto pipe stands capable of supporting the mast (weight is approximately $360 \mathrm{~kg}$ [800 1b] minimum of 3 pipe stands required) near the two lift points (leave room for arm motion to occur).

4.3.5.5 Remove the split-half nylon spacer rings from the deployment device body and store for reuse. Remove any other protective equipment from the deployment device at this time.

4.3.5.6 If the riser length is greater than $4.3 \mathrm{~m}(14 \mathrm{ft})$, install the vertical pipe spacer according to $\mathrm{H}-14-100458^{*}$.

4.3.5.7 If the dome head space (distance from the bottom of the riser to the top of the waste surface) is less than $3.8 \mathrm{~m}(12.5 \mathrm{ft})$, refer to the work package, because some arm spacers may need to be removed.

\subsection{EQUIPMENT STAGING AND INSTALLATION FOR LOWMMS}

Equipment staging and installation for the LOWMMS is covered in Section 5.3.

\subsection{OPERATING PROCEDURE}

\subsection{DAV STARTUP SEQUENCE}

\subsubsection{Electrical Cable Connections}

5.1.1.1 Set the mode selector switch on the power distribution panel to SMMS or LOWMMS depending on which type of scan is to be performed. This switch directs the appropriate position encoder signal (SMMS or LowMS probe) to the computer and the appropriate probe sigial to the nim-bin.

5.1.1.2 Verify that the following circuit breakers and disconnect switches are in the OFF position:

- Van power distribution pane1: a11 circuit breakers, CB-1 through CB-15 (see Figure 5.1)

- Van generator: $A C$ circuit breaker.

5.1.1.3 Ground the DAV. Attach the DAV grounding cable to a good ground such as a tank riser or grounding rod according to the site specific procedure.

*To be issued. 
5.1.1.4 For SMMS operation, connect the electrical cables to the equipment as follows.

NOTE: Electrical cabling interconnections are shown in Figure 5.2. Depending on whether a SMMS or LOWMMS scan is being performed some cables will not be connected, as identified above.

- W1 to DAV J1 and to SMMS electrical junction box J11 (probe signals)

- W7 to DAV J7 and to SMMS electrical junction box J17 (auxiliary instrument signais)

- W8 to DAV J8 and to SMMS electrical junction box J18 (auxiliary instrument signals)

- W9 to DAV $J 9$ and to SMMS electrical junction box J19 (probe signals)

- Optiona1: W3 to generator 33 (for generator power) or connect W2 to DAV P3 (to supply power. from a site service receptacle).

5.1.1.5 For LOWMMS operation, connect the cables as follows.

- W4 to spider box 34 (remote pendant controller)

- W5 to DAV J5 and to spider box J15 (probe cable)

- W6 to DAV J6 and to spider box J16 (spider cable)

- Optiona7: W3 to generator J3 (for generator power) or connect W2 to DAV P3 (to supply power from a site service receptacle).

\subsubsection{Supply Power to Data Acquisition Van}

Power for the computer system and electronics in the DAV can be achieved in one of three ways: the van's batteries, a site service receptacle, or the van's generator. Using power from the batteries is quiet and is therefore the preferred method. Recharge of the batteries may be performed by a site service receptacle or the van's generator. Discharged batteries take approximately 5 hours to recharge. The batteries can be connected to a site service receptacle overnight to recharge, but without overcharging the batteries.

\subsubsection{Battery.}

SMMS: $\quad$ Move the van power distribution pane1 circuit breaker switches $\mathrm{CB}-1, \mathrm{CB}-4, \mathrm{CB}-5 ; \mathrm{CB}-7, \mathrm{CB}-8, \mathrm{CB}-10, \mathrm{CB}-11$, and $C B-13$ (Figure 5.1) to the ON position. 
LOWMMS: Move the van power distribution pane1 circuit breaker switches $\mathrm{CB}-1, \mathrm{CB}-4, \mathrm{CB}-6, \mathrm{CB}-7, \mathrm{CB}-9, \mathrm{CB}-10$, and $\mathrm{CB}-13$ (Figure 5.1 ) to the oN position.

NOTE: The uninterruptible power supply will beep when the batteries are 70w. Depending on battery 7oad, a low battery warning may indicate there are only a few minutes of power remaining before shut down is imminent. If this warning occurs, auxiliary power using the generator or site service receptacle should be supplied as soon as possible. If the generator or site service receptacle are unavailable, the van must be relocated to an area where a receptacle is available to recharge the batteries.

\subsubsection{Site Service Receptacle.}

5.1.2.2.1 Using a multimeter, verify that the voltage across hot and neutral on the site service receptacle is 120 VAC. Verify that the voltage across neutral and ground is approximately zero.

5.1.2.2.2 Plug the extension cord into the van receptacle.

NOTE: The van line voltage receptacle is located on the right side of the van.

5.1.2.2.3 Plug the extension cord into the site service receptacle.

5.1.2.2.4 With the circuit breaker and switches (identified in Section 5.1.1.1) stit1 in the OFF position, move the site service disconnect switch to the oN position (if it had been $O F F)$. See the work package for the location of the disconnect switch for the particular tank farm.

5.1.2.2.5 Move the van power distribution panel circuit breakers as specified in Section 5.1.2.1 above to the ON position.

\subsubsection{Generator.}

\section{WARNING}

Generator exhaust piping becomes hot during operation and remains hot for a while after it is turned off. Do not touch the muffler while it is hot.

\section{WARNING}

The generator is a potential source of electrical shock if misused. Do not expose the generator to moisture, rain, or snow. Do not operate the generator if it is wet, and do not operate it with wet hands. 


\section{WARNING}

If the Co monitor warning signal occurs, turn off the van engine and/or generator, exit the van, and ventilate the van. Wait for a minimum of 5 minutes for the $\mathrm{CO}$ to dissipate. The $\mathrm{CO}$ monitor warning signal will automatically stop and reset when the unsafe CO level no longer exists.

5.1.2.3.1 Perform preoperation check.

NOTE: Engine oil is a major factor affecting engine performance and service 7ife. Nondetergent and 2-stroke engine oils will damage the engine and are not recommended.

1. Check the oil level BEFORE EACH USE with the generator on a level surface with the engine stopped. If the level is low, add SAE 30W SF/SG or equivalent 017 to the upper mark on the dipstick.

2. Check the fuel level gauge. Refill the tank if the fuel level is low. Do not fill above the shoulder or the fuel strainer, and never refuel if the generator is running or is hot.

5.1.2.3.2 Plug one end of the extension cord into the $A C$ receptacle on the generator and the other end into the van receptacle.

NOTE: The van line voltage receptacle is located on the right side of the van.

5.1.2.3.3 Make sure that the generator AC circuit breaker is in the OFF position. The generator may be hard to start if a load is connected.

5.1.2.3.4 Turn the fuel valve to the oN position, turn the choke lever to the CLOSE position, and turn the engine switch to the ON position.

5.1.2.3.5 Puil the starter grip until compression is felt, then pull briskly.

NOTE: Do not allow the starter grip to snap back. Return it slowly by hand to prevent damage to the starter.

5.1.2.3.6 Turn the choke lever to the OPEN position as the engine warms up.

5.1.2.3.7 Switch ON the generator AC circuit breaker. 
5.1.2.3.8 Move the van power distribution panel circuit breakers as specified in Section 5.1.2.1 above to the ON position.

Power is now available for the SMMS or LOWMMS components.

\subsubsection{Software Startup}

5.1.3.1 Verify the computer operating system has been started up. The computer screen will show the Windows ${ }^{1}$ interface with two icons: SMMS and LOWMMS.

5.1.3.2 Touch SMMS for SMMS.VI front pane?.

Touch LOW for LOWMMS.VI front panel:

NOTE: To temporarily suspend the LabVIEW program, touch the LabVIEW STOP icon. Operation is resumed by touching the RUN icon.

\subsubsection{Data File Access}

5.1.4.1 Switch from LabVIEW to the Windows program manager by simultaneously pressing the ALT and TAB keys.

5.1.4.2 Open the ACCESSORIES window, then touch the WRITE icon.

5.1.4.3 In the file menu, select "OPEN...".

5.1.4.4 Select a file from the file selector box:

-- C:IDATA|SMMS $\backslash m m-d d-y y \backslash m m-d d-y y .001$ (to access SMMS files)

-- C::DATA|LOWMMS \mm-dd-yy \mm-dd-yy.001 (to access LOWMMS files)

The "mm-dd-yy" refers to the current month, day, and year, respectively.

\subsection{SMMS OPERATING PROCEDURE}

If only a LOW scan is to be performed, the steps in this section are not performed. Continue with Section 5.3.

${ }^{1}$ Windows is a trademark of Microsoft Corporation. 


\subsection{Attach Neutron Source to Probe}

\section{WARNING}

Failure to handle the probe and source carefully, quickly; and maintaining a maximum distance can result in severe neutron overexposure. Approximate dose rate at $1 \mathrm{~m}$ ( $3 \mathrm{ft}$ ) is $30 \mathrm{mrem} / \mathrm{h}$ (see Figure 3.1 ).

\section{CAUTION}

Thread damage may occur without proper care in handling of the probe.

5.2.1.1 Open the source transfer cask (H-14-100554).

5.2.1.2 Remove the bagged, long-handled, source-handling tool

(H-14-100552)* with the source attached from the transfer cask (see Figure 5.3).

NOTE: $\quad$ For the first SMMS installation, the SMMS (including the source) will be clean and not stored inside a containment bag. Therefore, the glove bag will not be required for installing the source for the first time.

5.2.1.3 Place the long-handled tongs (H-14-100555\%, long-handled source tool (H-14-100552*) with source attached, calibration fixtures (H-14-100557*, H-14-100558\%, disposable stainless steel sleeve $(\mathrm{H}-14-100458 \mathrm{H}$, and scissors inside of the glove bag and install the glove bag around the end of the SMMS deployment device.

5.2.1.4 Cut the plastic away from the tool and remove the plastic to expose the source using the long-handled tongs.

5.2.1.5 Cut the plastic away from the probe and remove the plastic to expose the probe using the long-handled tongs.

5.2.1.6 Using the long-handled source handling tool, thread the source securely into the probe bottom by rotating the tool's outer handle clockwise.

5.2.1.7 When the source is secure in the probe, release the source as quickly as possible by rotating the tool's center handle counterclockwise.

5.2.1.8 Perform probe calibration as specified in Section 5.4.

*To be issued. 
5.2.1.9 Insta11 the disposable stainless steel sleeve to the end of the probe as specified in H-14-100458.

\subsubsection{Instal1 SWHS Deployment Device in Tank Riser}

5.2.2.1 Disable power to the deployment device electrical components by moving circuit breaker switches $C B-7, C B-10$, and $C B-13$ to the OFF position.

5.2.2.2 Disconnect instrument cables W1, W7, W8, and W9 from the deployment device electrical junction box (see Figure 5.2).

5.2.2.3 Visually verify that the deployment arm is aligned with the mast as shown in H-14-100458 and that there is no excess cable slack. Confirm that the decontamination spool piece and impact 1 imiters are installed.

5.2.2.4 Instal] the plastic containment bag around the deployment device mast, under the flange, for contamination control.

5.2.2.5 Lift the deployment device to vertical and position over the riser according to the critical lift procedure.

NOTE: Remove and discard the old plastic containment bag as the deployment device is inserted into the riser following standard radiological handling procedures (does not apply to first instal7ation).

5.2.2.6 Remove the upper (ta11) impact limiter when the deployment device flange (impact plate) is within $60 \mathrm{~cm}(2 \mathrm{ft})$ of the top of the impact Timiter set.

5.2.2.7 Remove the lower (short) impact 1 imiter when the impact plate is within $5 \mathrm{~cm}$ (2 in.) of the top of the lower impact limiter. Lower the deployment device to seat the impact plate on the spray washer. Bolt the plate in place.

5.2.2.8 Disconnect crane rigging from the deployment device lifting bail. The crane will not be needed again until the deployment device is retrieved as specified in Section 5.2.8.

5.2.2.9 Reconnect instrument cables W1, W7, W8, and W9 from the deployment device electrical junction box (see Figure 5.2).

5.2.2.10 Supply power to the deployment device electrical components by moving circuit breaker switches $C B-7, C B-10$, and $C B-13$ to the $O N$ position.

5.2.2.11 Connect the in-tank camera cable to the video monitoring system located in the van. 


\subsubsection{Position Probe for Moisture Measurement}

5.2.3.1 Verify the probe winch indicator displays 0.00 (reset if necessary). Lower the probe approximately $15 \mathrm{~cm}$ (6 in.) by rotating the probe winch clockwise. The probe needs to clear the arm's probe socket before the arm can be lifted. Confirm that the probe winch indicator displays $15 \mathrm{~cm}$ (6 in.).

5.2.3.2 Using the in-tank camera and the remote video monitor, pan for obstructions and set the two stop cTamps as required so that the deployment device cannot rotate past the obstructions.

5.2.3.3 Rajse the arm by rotating the arm winch clockwise.

5.2.3.4 Set the in-tank camera to view the probe location.

5.2.3.5 Using the remote video monitor, lower the probe to within a few inches of the waste.

\section{CAUTION}

Guide and lower probe to the waste surface carefully. Do not allow the probe to sink into the waste or compress the waste because this may lead to errors in the moisture measurement. Refer to the test procedure for probe placement guidel ines.

5.2.3.6 Locate the probe at the first measurement point. Guide and lower the probe onto the waste surface by rotating the probe winch clockwise.

\subsubsection{Perform Moisture Measurements}

5.2.4.1 Wait for probe temperature to stabilize. A red 1ight on the SMMS.VI front pane1 will indicate that the computer system is waiting for the probe temperature to stabilize. When the light turns green, the system is ready to take a moisture measurement.

5.2.4.2 Initiate data collection by selecting the TAKE MEASUREMENT icon.

NOTE: Data collection takes approximately one to five minutes to complete. Collection is complete when the Third Tube display is finished with its update.

5.2.4.3 After data collection at the first point is completed, raise the probe from the surface, rotate the deployment device to the desired azimuthal angle using the electronic compass readout, and again lower the probe onto the waste surface. 
NOTE: Refer to the test p7an for specific safety and/or placement controls.

5.2.4.4 Repeat the steps in Sections 5.2.4.1 through 5.2.4.3 unti 1 the total required number of readings have been taken at the current arm radial position.

5.2.4.5 Raise the probe a few feet from the waste. Adjust the deployment arm inclination angle corresponding to the new radial position. The position of the probe is shown on the SMMS.VI front panel display in the DAV. Lower the probe onto the waste surface. Repeat the steps in Sections 5.2.4.1 through 5.2.4.4.

5.2.4.6 Repeat the step specified in Section 5.2.4.5 until all test points as dictated by the tank specific test $\mathrm{plan}$ have been completed.

\subsubsection{Terminate LabVIEW and Archive data}

5.2.5.1 Touch the STOP icon.

5.2.5.2 Touch FILE to open the file menu, then select EXIT from the file menu. This will return the user to the Windows interface.

5.2.5.3 Select EXIT WINDOWS from the file menu.

5.2.5.4 Touch OK to end Windows session.

5.2.5.5 Insert diskette into Drive A: .

5.2.5.6 At the DOS prompt $(C: \mid>)$, type:

copy $c: \backslash$ data $\backslash S M M S \backslash m m-d d-y y \backslash{ }^{*}{ }^{*}$ a: (command to copy SMMS files) copy c: $\mid$ data $\backslash$ LOWMMS $\backslash m m-d d-y y \backslash * *$ a: (command to copy LOWMMS files)

This will copy all files that were created on this day to the diskette. The "mm-dd-yy" refers to the current month, day, and year, respectively.

\subsubsection{Prepare Deployment Device for Removal}

5.2.6.1 Raise the probe by rotating the probe winch counterclockwise until it is within approximately $15 \mathrm{~cm}(6$ in.) of the end of the arm. The probe needs to clear the $\mathrm{arm}^{\text {is }} \mathrm{p}$ probe socket before the arm can be raised or lowered.

5.2.6.2 Lower the deployment arm to the vertical position by rotating the arm winch counterclockwise. 
5.2.6.3 Raise the probe until the probe is secured in the socket of the arm by rotating the probe winch counterclockwise.

5.2.6.4 Verify the probe is secured in the socket of the arm using the in-tank camera.

5.2.6.5 Disable power to the deployment device electrical components by moving circuit breaker switches $\mathrm{CB}-7, \mathrm{CB}-10$, and $\mathrm{CB}-13$ to the OFF position.

5.2.6.6 Disconnect instrument cables $W 1, W 7$, W8, and W9 from the deployment device electrical junction box (see Figure 5.2).

\subsubsection{Retrieve Deployment Device from Riser}

5.2.7.1 Slowly retrieve the deployment device from the riser according to the critical lift procedure. Monitor contamination and decontaminate as specified in Section 5.2.8. When contamination is found, tape off the top of the bag to the deployment device mast. Continue bagging the deployment device as it is removed from the riser.

NOTE: Reinstal7 the lower (short) impact limiter when the deployment device flange (impact plate) is $25 \mathrm{~cm}$ (10 in.) above the decontamination spool piece flange. Reinstal7 the upper impact 7imiter when the deployment device impact plate is $1.7 \mathrm{~m}(5.6 \mathrm{ft})$ above the top of the lower impact limiter. Reinstal7 the midpoint lifting clamp according to H-14-100458 and the critical 7 ift procedure.

\section{WARNING}

Failure to maintain maximum distance from the probe as it is removed from the riser can result in severe neutron overexposure. Approximate dose rate at $1 \mathrm{~m}$ (3 ft) is $30 \mathrm{mrem} / \mathrm{h}$ (see Figure 3.1). Use the provided remote-handling tools for bagging the deployment device and probe.

5.2.7.2 Raise the deployment device $1 \mathrm{~m}(3 \mathrm{ft})$ above the top of the impact limiter set. DO NOT exceed this height.

5.2.7.3 While maintaining a minimum distance of $1 \mathrm{~m}(3 \mathrm{ft}$ ) from the probe bottom, seal off the bottom of the plastic containment bag by tightly bunching the bag and taping thoroughly in two places. Cut the bag between the two taped locations.

5.2.7.4 After the deployment device is clear of the tank riser, close the riser according to the tank farm work package procedures. 
5.2.7.5 Using the crane, lower the deployment device from vertical to horizontal according to the critical 1 ift procedure and reset on the pipe stands.

5.2.7.6 Install the large glove bag around the bottom of the deployment device. Place the long-handled tongs ( $H-14-10055^{\circ}$, long-handled pry bar, long-handled source tool (H-14-100552\%, cal ibration fixtures $(H-14-100557, \mathrm{H}-14-100558 \%$, and scissors inside of the glove bag.

5.2.7.7 Cut away the plastic bag from the bottom of the probe and pull the plastic away to completely uncover the probe using the long-handled tongs.

5.2.7.8 Using long-handied pry bar, remove and discard the probe bottom stainless steel sleeve (see H-14-100458 following standard radiological handling procedures.

5.2.7.9 Reconnect instrument cables W1, W7, W8, and W9 to the deployment device electrical junction box (see Figure 5.2).

5.2.7.10 Supply power to the deployment device electrical components by moving circuit breaker switches $C B-7, C B-10$, and $C B-13$ to the $O N$ position.

5.2.7.11 Perform probe calibration according to Section 5.4 to verify equipment is still functioning correctly.

\subsubsection{Operate Decontamination System}

To minimize water addition to the waste tank, the decontamination system will be used only if needed. Because only the bottom of the probe contacts the waste surface, it is expected that most of the SMMS deployment device will be decontaminated using rags or equivalent standard tank farm techniques. The deployment device will be monitored for contamination as it is withdrawn. If high levels of contamination are detected by health physics technician monitoring, the decontamination system will be operated as follows.

\section{WARNING}

The feed pump and high pressure pump exhaust piping becomes hot during operation and remains hot for a while after it is turned off. Do not touch a muffler while it is hot.

5.2.8.1 Verify that antifreeze has been flushed from the pumps if they have been winterized with antifreeze. Check the gasoline level of pumps and refill if necessary. Check the motor oil level on the pumps and fill with SAE $30 \mathrm{~W}$ SF/SG 011 as required.

* To be issued. 
5.2.8.2 Verify detergent valve on the high pressure pump is in the closed position.

5.2.8.3 Connect the decontamination equipment hoses to the water supply tank, feed pump, high pressure washer, and decontamination spool piece as specified in H-14-100462. Figure 5.5 shows the basic 1ayout of the decontamination system.

5.2.8.4 Verify tank is filled with clean, cold water.

5.2.8.5 Purge hoses by opening valves HV-1 and HV-2 according to

Figure 5.5. Disconnect the hose from the high-pressure pump to the hose reel.

\section{CAUTION}

Do not run the feed pump for more than 5 minutes with water flowing through HV-1. Never run the high-pressure pump without adequate water supply. Pump and system overheating can occur.

5.2.8.6 Start the feed pump ( 30 psig maximum output), if necessary, to purge air from the hoses. C1ose HV-2 after purge.

5.2.8.7 Turn off the feed pump and reconnect the hose from the high-pressure pump to the hose ree1.

5.2.8.8 Record the initial reading on the 5/8-in. totalizer in the tank farm work package.

NOTE: A larger 1 1/2-in. water meter is supplied with the feed pump skid, but is not used for SMMS decontamination.

5.2.8.9 Start the feed pump.

5.2.8.10 Position the deployment device so that the area requiring decontamination is in the spray washer.

5.2.8.11 Open valve HV-2.

5.2.8.12 Start the high pressure pump. (The pump supplies approximately $3.5 \mathrm{gpm}$ at 1,500 psi when connected per this procedure).

NOTE: Shut off the high pressure pump and close valve HV-2 whenever removal stops, or at the discretion of the tank farm person-in-charge.

*To be issued. 


\section{CAUTION}

Do not lift the deployment device clear of the rubber wiper while the decontamination system is operating. The spray water will not be adequately contained.

5.2.8.13 Spray for approximately 5 minutes or longer until contamination levels are within acceptable limits according to the health physics technician's direction. Raise, lower, and turn the deployment device as required to facilitate decontamination.

5.2.8.14 Shut off the high-pressure pump at the end of the decontamination process.

5.2.8.15 Shut off the feed pump and close valves HV-I and HV-2.

5.2.8.16 Read the water meter and record the total water addition in the tank farm work package.

\subsubsection{Remove Neutron Source from Probe}

The steps in this section may be skipped if a SMMS deployment in another riser is to be immediately performed.

5.2.9.1 With the long-handled, source-handling tool ( $H-14-100552)^{*}$ inside the glove bag, attach the tool into the nut in the source by turning the center handle clockwise.

\section{WARNING}

Failure to handle the probe and source carefully or keep it at a maximum distance can result in severe neutron overexposure. Approximate dose rate at $1 \mathrm{~m}(3 \mathrm{ft})$ is $30 \mathrm{mrem} / \mathrm{h}$ (see Figure 3.1).

\section{CAUTION}

Thread damage may occur without proper care in handling of the probe.

5.2.9.2 Rotate the tool outer handle counterclockwise to release the source from the probe. Remove the source from the probe.

*Tō be issued. 
5.2.9.3 Bag-out the source and tool from the glove bag and insert the assembly into the source transfer cask (see Figure 5.3).

5.2.9.4 Insert the shielding plug into the source transfer cask.

5.2.9.5 Secure the source transfer cask by replacing the lock and shielding.

5.2.9.6 Bag-out the remaining tools and calibration fixtures from the glove bag and store in accordance with the tank farm work package.

\subsubsection{Reinsta11 Deployment Device into Container}

The steps in this section may be skipped if a SMMS deployment in another riser is to be immediately performed.

5.2.10.1 Disable power to the deployment device electrical components by moving circuit breaker switches $\mathrm{CB}-7, \mathrm{CB}-10$, and $\mathrm{CB}-13$ to the OFF position.

5.2.10.2 Disconnect instrument cables $W 1, W 7$, W8, and Wg from the deployment device electrical junction box (see Figure 5.2).

5.2.10.3 Reinstall the spljt half nylon spacer rings on the deployment device body. Replace any other protective equipment that was removed from the deployment device at this time.

5.2.10.4 Attach the crane to the hoist rings at the top of the deployment device with the appropriate rigging. Attach the crane boom to the midpoint lifting clamp with the appropriate rigging.

5.2.10.5 Slide the deployment device into the container, removing the midpoint lifting clamp from the deployment device when required. Support the deployment device with cranes and/or pipe-stands during this process to prevent damage from bending.

5.2.10.6 Install and torque the $8 \mathrm{fl}$ ange nuts and bolts, securing the deployment device to the storage container.

\subsubsection{Disable Power to Data Acquisition Van}

5.2.11.1 Move all circuit breaker switches on the van power distribution panel (CB-1 through CB-15) to the OFF position.

5.2.11.2 If the system is powered from the field source, turn the site service disconnect to the OFF position if required by standard site practices.

5.2.11.3 If the system is powered from the generator, perform the following steps. 


\section{WARNING}

Generator exhaust piping becomes hot during operation and remains hot for a while after it is turned off. 'Do not touch the muffler while it is hot.

5.2.11.3.1 Turn the $A C$ circuit breaker to the OFF position.

5.2.11.3.2 Move the engine switch to the OFF position.

5.2.11.3.3 Turn the fuel valve to the OFF position.

\subsubsection{Disconnect Cables and Hoses}

5.2.12.1 Disconnect al1 instrumentation and power cables connected to the DAV.

5.2.12.2 After a health physics technician surveys the cables and hoses, store in an appropriate location.

5.2.12.3 Disconnect the decontamination water hoses from the water tank (or tanker truck), feed pump, pressure washer, and decontamination spool piece.

5.2.12.4 Winterize the pumps per manufacturer's instructions if the system will be stored in below freezing conditions. Drain or blow out the decontamination spool piece.

\subsection{LOWMHS OPERATING PROCEDURE}

\subsubsection{System Startup Sequence}

5.3.1.1 Connect electrical cables, supply power to DAV, and startup software as specified in Section 5.1.

NOTE: Computer screen should display LOWMMS.VI pane].

5.3.1.2 Position the DAV near the LOW and point the van boom toward the LOW.

5.3.1.3 Thread the probe cable through the pulleys on the rotating boom and connect the cable to the probe as specified in drawing $\mathrm{H}-14-100465$

*To be issued. 


\subsubsection{Attach Neutron Source to Probe}

\section{WARNING}

Failure to handle the probe and source carefully or keep it at a maximum distance can result in severe neutron overexposure. Approximate dose rate at $1 \mathrm{~m}$ (3 ft) is $6 \mathrm{mrem} / \mathrm{h}$ (see Figure 3.2).

\section{CAUTION}

Thread damage may occur without proper care in handling of the probe.

5.3.2.1 Open the source storage cask $(H-14-100556)^{*}$.

5.3.2.2 Attach the long-handled, source-handling tool (H-14-100294) into the nut in the source by turning the center handle clockwise (see Figure 5.4).

5.3.2.3 Rotate the tool's outer handle counterclockwise to remove the source from the anchor bolt.

NOTE: Assistance will be needed to hold the probe as the source is attached.

5.3.2.4 Thread the source securely into the probe by rotating the tool's outer handle clockwise.

5.3.2.5 When the source is secure in the probe, release the source as quickly as possible by rotating the tool's center handle counterclockwise.

5.3.2.6 Perform probe calibration as specified in Section 5.4.

\subsubsection{Check Liquid Observation Well for Cleanliness}

5.3.3.1 Obtain a 100-ft tape with a heavy metal ring (donut) attached.

5.3.3.2 Tie and tape a rag to the donut.

5.3.3.3 Remove the LOW plug to gain access to the LOW.

5.3.3.4 Check the LOW for flammable gas using a combustible gas meter. STOP WORK and contact management if high levels of flammable gas are detected as specified in the tank farm work package.

*To be issued. 
5.3.3.5 Lower the donut into the LOW to check for dampness and presence of contamination, leave the donut on the bottom of the Low long enough to absorb any moisture.

5.3.3.6 ReeT up the donut towards the top of the LOW and monitor for contamination as it nears the top of the LOW.

\section{WARNING}

An increase in the radiation or flammable gas reading could indicate a breached LoW. If an increase is detected, the donut should not be removed from the LOW.

5.3.3.7 If an increase in the radiation reading occurs, perform the following.

5.3.3.7.1 Lower the donut into the LOW.

5.3.3.7.2 Reinsta11 the LOW plug.

5.3.3.7.3 Seal the LOW plug in place with tape, STOP WORK, and NOTIFY MANAGEMENT.

5.3.3.8 If no increase in radiation reading occurs, perform the following.

5.3.3.8.1 Remove the donut for the LOW.

5.3.3.8.2 Check the donut for contamination.

5.3.3.8.3 If no contamination is found, place the reel and donut into a plastic bag and discard following standard radiological handling procedures.

5.3.3.8.4 Continue to Section 5.3.4.

\subsubsection{Position LoWwS Equipment on Liquid Observation We11}

5.3.4.1 Carry the spider assembly and probe about $0.3 \mathrm{~m}$ (1 ft) past the LOW, using the pendant controller to pay out the cable.

5.3.4.2 Lower the probe into the LOW about 0.3 to $0.9 \mathrm{~m}$ ( 1 to $3 \mathrm{ft}$ ).

5.3.4.3 Position the spider on the LOW flange with the probe cable centered in the hole of the spider.

5.3.4.4 Align the pulleys with the van boom and clamp the spider to the LOW flange using two vise grips. 
5.3.4.5 Align the probe cable with the guide pulleys. Pull the knurled knob on the retractable plunger, and rotate the upper guide pulley to secure the probe cable in place. Release the knurled knob and verify that the plunger is inside the slot on the upper pulley arm.

5.3.4.6. Verify that the probe cable is aligned correctly on the spider pulleys as specified in $\mathrm{H}-14-100465^{*}$ and is properly aligned in the van boom's pulley.

5.3.4.7 Verify that the cables are connected as shown in Figure 5.2.

\subsubsection{Perform Liquid Observation Well Scan}

\section{CAUTION}

Moving the boom or van, or touching or grasping the cable after the probe has entered the LoW could result in probe damage or incorrect readings for the scan.

5.3.5.1 Verify that the LOW to be used for moisture measurement is properly identified. Using the bar code reader, scan the bar code on the LOW.

5.3.5.2 Enter scan parameters as required. Default parameters will be used for the scan if none are entered.

5.3.5.3 Press the START button on the LOWMMS.VI pane1.

NOTE: A normal scan will let the probe pause at the bottom of the LOW for approximately two seconds, then begin to ascend at a predetermined rate, stopping and taking data at the proper interva7s. When data collection is complete, the probe should automatically accelerate, return to the surface, and stop.

5.3.5.4 Monitor the scan in progress for proper data acquisition.

5.3.5.5 If the scan cannot be successfully completed, perform the following steps.

NOTE: If the software cable slack alarm occurs, perform the steps specified in Section 8.2.1.

5.3.5.5.1 Record the indicated depth.

5.3.5.5.2 Press the STOP button on the LOWMMS.VI panel.

*To be issued. 
5.3.5.5.3 Retrieve the probe from the LOW using the remote pendant controller.

5.3.5.5.4 Repeat the steps in Sections 5.3.5.2 through 5.3.5.4 or contact engineering for guidance.

5.3.5.6 After the scan is complete, perform probe calibration according to Section 5.4 to verify equipment is still functioning correctly.

5.3.5.7 Repeat the steps in Sections 5.3.5.2 through 5.3.5.5 using the other probe as required. See Sections 5.3.6 and 5.3.7 for removing the source and changing probes.

\subsubsection{Remove Neutron Source from Probe}

5.3.6.1 Remove the spider assembly and the probe from the LOW flange. Disengage the probe from the center of the spider.

\section{WARNING}

Failure to handle the probe and source carefully or keep it at a maximum distance can result in severe neutron overexposure. Approximate dose rate at $1 \mathrm{~m}(3 \mathrm{ft}$ ) is $6 \mathrm{mrem} / \mathrm{h}$ (see Figure 3.2).

5.3.6.2 Using remote means for exposure contro1, wipe the probe and source with clean cloths as required.

NOTE: Assistance will be needed to hold the Probe as the source is removed.

5.3.6.3 Attach the long-handled, source-handling tool (H-14-100294) into the nut in the source by turning the center handle clockwise.

\section{CAUTYON}

Thread damage may occur without proper care in handling of the probe.

5.3.6.4 Rotate the tool's outer handle counterclockwise to release the source from the probe. Remove the source using the source-handling tool.

NOTE: If a scan is to be performed with another probe, the steps in Sections 5.3.6.5 through 5.3.6.10 are not performed at this time. Keep the neutron source away from personnel to 
limit exposure while changing detector probe as specified in Section 5.3.7.

5.3.6.5 Using the source-handling tool, insert the source into the source storage cask.

5.3.6.6 Thread the source securely into the source storage cask by rotating the tool's outer wheel clockwise (see Figure 5.4).

5.3.6.7 After the source is secure in the source storage cask, release the source from the tool by rotating the tool's center wheel counterclockwise.

5.3.6.8 Remove the tool from the source storage cask.

5.3.6.9 Insert the shielding plug into the source storage cask.

5.3.6.10 Secure the source storage cask by replacing lock and shielding.

\subsubsection{Change Detector Probe}

5.3.7.1 Shut off power to the probe by moving circuit breaker switches $\mathrm{CB}-10$ and $\mathrm{CB}-13$ (see Figure 5.1) to the OFF position.

\section{WARNING}

Failure to ensure that the power is off before changing a detector probe could result in electrical shock.

5.3.7.2 Verify neutron source has been removed as specified in Section 5.3.6.

5.3.7.3 Loosen the knurled nut connection.

5.3.7.4 Carefully remove the cable plug from the probe receptacle.

5.3.7.5 Check fitting in new probe for cleanliness and water. Clean if necessary.

5.3.7.6 Insert the cable plug into the new probe and tighten the knurled nut connection.

5.3.7.7 Supply power to the new probe by moving circuit breaker switches $\mathrm{CB}-10$ and $\mathrm{CB}-13$ to the ON position.

5.3.7.8 Repeat the steps in Sections 5.3.2 through 5.3.5 as required for the new probe. 


\subsubsection{System Shutdown}

5.3.8.1 Disable power to the DAV as specified in Section 5.2.11.

5.3.8.2 Disconnect all instrumentation and power cables and coil neatly for storage.

5.3.8.3 After a health physics technician surveys the cables, store in an appropriate location.

5.3.8.4 Secure the probe, spider assembiy, and boom for storage/transport.

\subsection{PROBE CALIBRATION CHECK}

Each probe will be calibrated before and after moisture measurements to verify the equipment is functioning properly. Two fixtures each for the SMMS and LOWMMS probes will be used for performing this calibration.

\subsubsection{SMMS Probe}

5.4.1.1 Place SMMS calibration fixture \#1 (H-14-100557) around the probe.

5.4.1.2 Touch the TAKE MEASUREMENT icon on the SMMS.VI front pane1.

NOTE: Wait until the green light appears indicating that the probe temperature has stabilized before touching the TAKE MEASUREMENT icon.

5.4.1.3 Apply correction factor to the count rate for source decay.

5.4.1.4 Verify that the count rate for each detector is within 2 percent of the specified value.

5.4.1.5 PTace SMMS calibration fixture \#2 (H-14-100558) around the probe and repeat the steps specified in Sections 5.4.1.1 through 5.4.1.4.

\subsubsection{LOWMMS Probes}

5.4.2.1 Place the probe in LOWMMS calibration fixture \#1 (H-14-100559)*.

5.4.2.2 Touch the START icon on the LOWMMS.VI front paneT.

5.4.2.3 Apply correction factor to the count rate for source decay.

5.4.2.4 Verify that the count rate for each detector is within 2 percent of the specified value.

5.4.2.5 Place the probe in LOWMMS calibration fixture \#2 (H-14-100560) and repeat the steps specified in Sections 5.4.2.1 through 5.4.2.4. 


\subsection{MAINTENANCE}

\subsection{HARDWARE CHANGE-OUT UNDER NORMAL CONDITIONS}

\subsubsection{Surface Moisture Measurement System}

[TBD-1 Section 6.1.1 SMMS hardware change-out procedures]

\subsubsection{Liquid Observation We11 Moisture Measurement System}

[TBD-2 Section 6.1.2 LOWMS hardware change-out procedures]

\subsection{PREVENTATIVE MAINTENANCE}

\subsubsection{Visual Inspection}

Visually inspect all components of the system for signs of damage or unusual wear. Inspect the DAV including the drawworks for cleanliness and clean as required.

\subsubsection{Generator}

See Owner's Manual for maintenance schedule and procedures for the following items:

- Engine oil change

- Air cleaner service

- Fuel sediment cup cleaning

- Spark plug service

- Spark arrester maintenance

- Valve clearance

- Fue1 tank and strainer cleaning

- Fuel line check.

\subsubsection{Mechanical and Electrical Checks}

Inspect a11 external cables for evidence of insulation damage or kinking after every use.

\subsubsection{Decontamination System}

Check high-pressure pump and feed-pump oil according to manufacturer's instructions. If oil is milky, indicating water contamination, replace with SAE 3OW non-detergent oil. 


\subsection{TROUBLESHOOTING}

The SMMS and LOWMMS are newly developed systems. The following individuals are the responsible engineers that should be contacted with any troubleshooting questions not addressed in the following sections:

$\begin{array}{ll}\text { Mike Gimera } & \text { DAV Electrical and Software } \\ \text { Jim Bussel1 } & \text { Probe Electrical } \\ \text { Dennis Graves } & \text { Mechanical } \\ \text { Troy Stokes } & \text { Overall System } \\ \text { G. F. Vargo, Jr. } & \text { Overall System } \\ \text { Jim Bates } & \text { PNL R\&D Engineer } \\ \text { Todd Watson } & \text { Nuclear Physicist }\end{array}$

\subsection{LOSS OF POWER}

If instrument power is not avaitable as evidenced by the computer not turning on as indicated by the OMM procedures, then the following steps should be taken.

\subsubsection{Check Circuit Breakers}

Recheck all circuit breakers on the control console (see Figure 5.1 for breaker locations).

NOTE: Circuit breakers move to the intermediate position when tripped.

\subsubsection{Check Fuses}

Using continuity tester, check fuses (reference $\mathrm{H}-14-100469 *$ H-14-100471*, H-14-100473*, H-14-100485, and H-14-100486* for fuse locations).

\subsection{COMPUTER SYSTEM FATLURE}

The computer system has failed if the program has terminated unexpectedly, or the computer screen is blank. Switch circuit breakers CB-7, $C B-10$, and $C B-13$ (see Figure 5.1) to the OFF position to shut off power to the computer and all instrumentation. After 30 seconds, reapply power to the computer. If the problem still exists, contact engineering.

\subsection{COMPUTER SOFTWARE ERRORS}

Detajled descriptions of computer software errors are provided in WHC-SD-WM-CSDD-017, for the SMMS, and WHC-SD-WM-CSDD-018* for the LOWMMS. If an error occurs, record the specific details of the software error and any displayed error messages. Contact engineering to initiate corrective action. 


\subsection{INSTRUWENT HARDWARE FAILURE}

Record the specific details of the hardware failure and any displayed error messages. Contact engineering to initiate corrective action.

\subsection{RESPONSE TO ABNORMAL CONDITIONS}

\subsection{GENERAL}

If, for any reason, the procedures specified in this OMM cannot be performed as written, STOP WORK, and contact engineering to initiate corrective action.

\subsection{SOFTWARE ALARHS}

\subsubsection{LOWMHS STack Cable Alarm}

The LOWMMS spider assembly has a cable slack detection sensor and the software will alarm if this sensor is tripped. If the software alarms during operation of the LOWMMS, the scan will automatically stop and a dialogue box will appear on the computer screen indicating that a slack cable has been detected. If this alarm occurs, check the following.

8.2.1.1 Inspect the spider assembly and boom to verify that the cable is correctly aligned on the guide pulleys. If the cable is not aligned correctly, realign cables, and restart scan. Press the START button again and observe that the probe is slowly retracted to the "home" position, indicating that the scan is finished.

8.2.1.2 If the cable is correctly aligned on the pulleys, a slack cable alarm may indicate that the LOWMMS probe has hit the bottom of the LOW or an obstruction within the LOW. Verify that the correct parameters have been entered for the LOW scan. If the wrong parameters were entered, reenter parameters by stopping the LOWMMS software and restarting the software. If the barcode reader is not functioning properly, enter the information manualiy. Repeat scan.

8.2.1.3 If the cable is correctly aligned, and the correct parameters have been entered, a slack cable alarm indicates that the probe has hit an obstruction in the LOW or the slack detection sensor is not functioning correctly. Remove probe from LOW using pendant controller and contact management to initiate corrective action. 


\subsection{REFERENCES}

Clements, M. D., 1996, Documentation and Analysis for Packaging for Surface Moisture 7A Containers, WHC-SD-TP-DAP-008, draft, Westinghouse Hanford Company, Richland, Washington.

Clements, M. D., 1996a, Safety Eva7uation for Packaging (SEP) Surface Moisture Equipment, WHC-SD-TP-SEP-043, draft, Westinghouse Hanford Company, Richland, Washington.

DOE-RL-92-36, Hanford Site Hoisting and Rigging Manua7, Department of Energy, Richland, Washington.

Gimera, M., 1996, Software Design Description for Surface Moisture Monitor, WHC-SD-WM-CSDD-017, draft, Westinghouse Hanford Company, Rich1 and, Washington.

Gimera, M., 1996a, Sof tware Design Description for LoW Moisture Monitor, WHC-SD-WM-CSDD-018, draft, Westinghouse Hanford Company, Richland, Washington.

HSRCM-1, Hanford Site Radiological Control Manual, Tatest revision, Westinghouse Hanford Company, Richland, Washington.

Meacham, J. E., H. Babad, R. J. Cash, G. T. Dukelow, S. J. Eberlein, D. W. Hamilton, J. L. Huckaby, G. D. Johnson, J. W. Osborne, M. A. Payne, D. J. Sherwood, and D. A. Turner, 1995, Approach for Tank Safety Characterization of Hanford Site Waste, WHC-EP-0843, Westinghouse Hanford Company, Richland, Washington.

Stokes, T. I., 1996, Surface Moisture Measurement System Design Description, WHC-SD-WM-SDD-066, draft, Westinghouse Hanford Company, Richland, Washington.

TF-95-0089, Surface Moisture Monitoring of Hanford Tank Waste by Neutron Activation, Westinghouse Hanford Company, Richland, Washington.

WHC-CM-1-6, WHC Radiological Control Manua7, latest revision, Westinghouse Hanford Company, Richland, Washington.

WHC-CM-2-14, Hazardous Material Packaging and Shipping, latest revision, Westinghouse Hanford Company, Richland, Washington.

WHC-IP-0972, Rev. 1, Source Movement Procedure, Westinghouse Hanford Company, Richland, Washington.

WHC-IP-1019, latest revision, Material Control and Accountability P7an, Westinghouse Hanford Company, Richland, Washington.

WHC-SD-QAPP-001, latest revision, Quality Assurance Program P7an for Source Contro7, Westinghouse Hanford Company, Richland, Washington. 
WHC, 1995, Neutron Moisture Probe Source Hand7ing Too7, May 1995, drawing H-14-100294, Rev. 0, Westinghouse Hanford Company, Richland, Washington,

WHC, 1996a, Surface Moisture Monitoring System Installation Assemb7y, drawing H-14-100458, draft, Westinghouse Hanford Company, Richland, Washington.

WHC, 1996b, Surface Moisture Monitoring System Deployment Enclosure, drawing H-14-100459, draft, Westinghouse Hanford Company, Richland, Washington.

WHC, 1996c, Surface Moisture Monitoring System Deployment Arm, drawing H-14-100460, draft, Westinghouse Hanford Company, Rich7and, Washington.

WHC, 1996d, Surface Moisture Monitoring System Neutron Detector Assemb7y, drawing H-14-100461, draft, Westinghouse Hanford Company, Richland, Washington.

WHC, 1996e, Surface Moisture Monitoring System Decon System Assemb7y, drawing H-14-100462, draft, Westinghouse Hanford Company, Rich7and, Washington.

WHC, 1996f, Surface Moisture Monitoring System Impact Limiter Assembly, drawing H-14-100463, draft, Westinghouse Hanford Company, Richland, Washington.

WHC, 1996g, Surface Moisture Monitoring System Vehicle Modifications, drawing H-14-100464, draft, Westinghouse Hanford Company, Richland, Washington.

WHC, 1996h, Surface Moisture Monitoring System Cable Assemb7ies, drawing H-14-100477, draft, Westinghouse Hanford Company, Richland, Washington.

WHC, 1996i, Low Probe Delivery System Assemb7y, drawing H-14-100465, draft, Westinghouse Hanford Company, Richland, Washington.

WHC, 1996j, Surface Moisture Monitoring System Block Diagram, drawing H-14-100467, draft, Westinghouse Hanford Company, Richiand, Washington.

WHC, 1996k, Surface Moisture Monitoring System Drawing Tree, drawing H-14-100457, draft, Westinghouse Hanford Company, Richland, Washington.

WHC, 19961, Operator Control Enclosure Surface Moisture Measurement System Wiring, drawing H-14-100469, draft, Westinghouse Hanford Company, Richland, Washington.

WHC, 1996m, Driver Side Electronics Enclosure Surface Moisture Measurement System Wiring, drawing H-14-100471, draft, Westinghouse Hanford Company, Richl and, Washington.

WHC, 1996n, Passenger Side E7ectronics Surface Moisture Measurement System Wiring, drawing H-14-100473, draft, Westinghouse Hanford Company, Richland, Washington.

WHC, 19960, Surface Moisture Measurement System Deployment Enclosure Wiring, drawing H-14-100485, draft, Westinghouse Hanford Company, Rich1and, Washington. 
WHC, 1996p, SMMS Source Handling Too7, drawing H-14-100552, draft, Westinghouse Hanford Company, Richland, Washington.

WHC, 1996q, SMMS Source Storage Cask Arrangement, drawing H-14-100554, draft, Westinghouse Hanford Company, Richland, Washington.

WHC, 1996r, SMMS Long Hand7ed Tongs, drawing H-14-100555, draft, Westinghouse Hanford Company, Richland, Washington.

WHC, 1996s, SMMS Calibration Fixture \#1, drawing H-14-100557, draft, Westinghouse Hanford Company, Richland, Washington.

WHC, 1996t, SMMS Calibration Fixture \#2, drawing H-14-100558, draft, Westinghouse Hanford Company, Richland, Washington.

WHC, 1996u, Surface Moisture Monitoring System Elementary Diagram, drawing H-14-100474, draft, Westinghouse Hanford Company, Rich1and, Washington.

WHC, 1996v, Liquid Observation Well Deployment Device Wiring Diagram, drawing H-14-100486, draft, Westinghouse Hanford Company, Richland, Washington.

WHC, 1996w, LOWMMS Source Storage Cask Arrangement, drawing H-14-100556, draft, Westinghouse Hanford Company, Richland, Washington.

WHC, 1996x, LOWMMS Calibration Fixture \#1, drawing H-14-100559, draft, Westinghouse Hanford Company, Rich1and, Washington

WHC, 1996y, LOWMMS Calibration Fixture \#2, drawing H-14-100560, draft, Westinghouse Hanford Company, Richland, Washington.

WHC, 1996z, SMMS Shipping/Storage Container, drawing H-14-100553, draft, Westinghouse Hanford Company, Richland, Washington.

VI 22719, Surface Moisture Measurement System Vendor Information, draft, Westinghouse Hanford Company, Rich1and, Washington. 
WHC-SD-WM-OMM-024 REV 0

Figure 1-1. Surface Moisture Meașurement System.

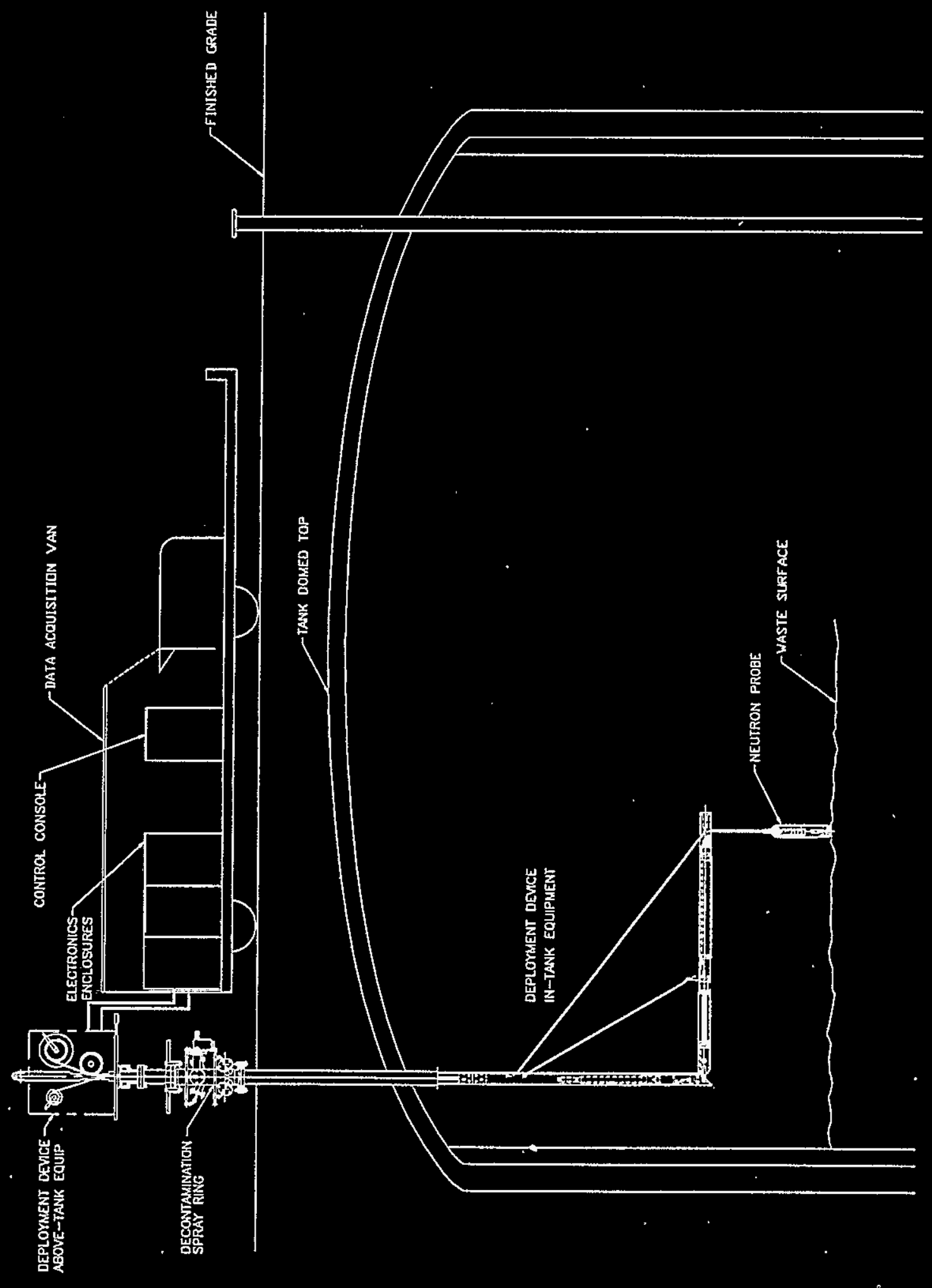


Figure 1-2. Liquid Observation We11 Moisture Measurement System.

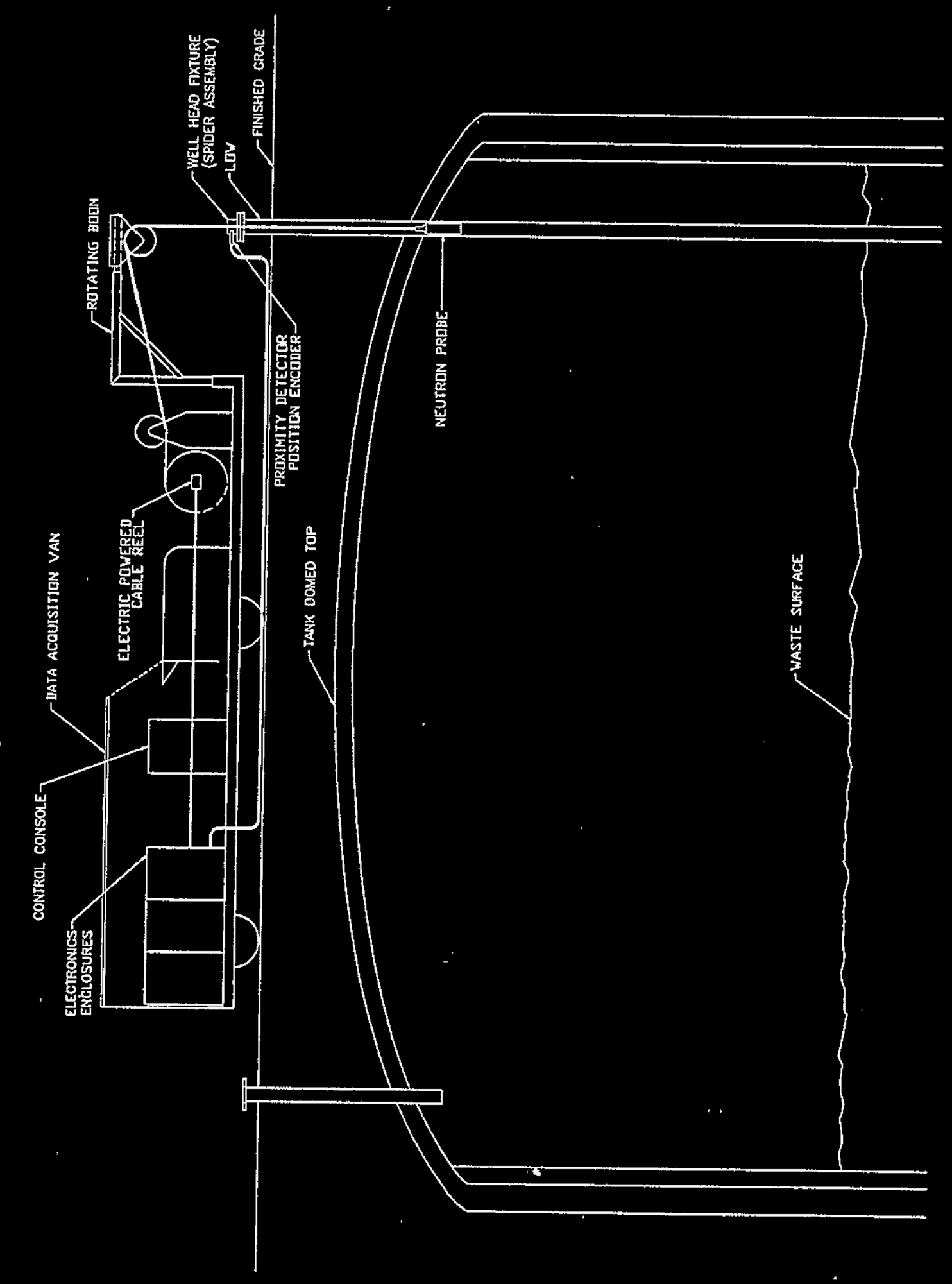


Figure 2-1. Layout of the Driver Side Cabinets in the DAV.
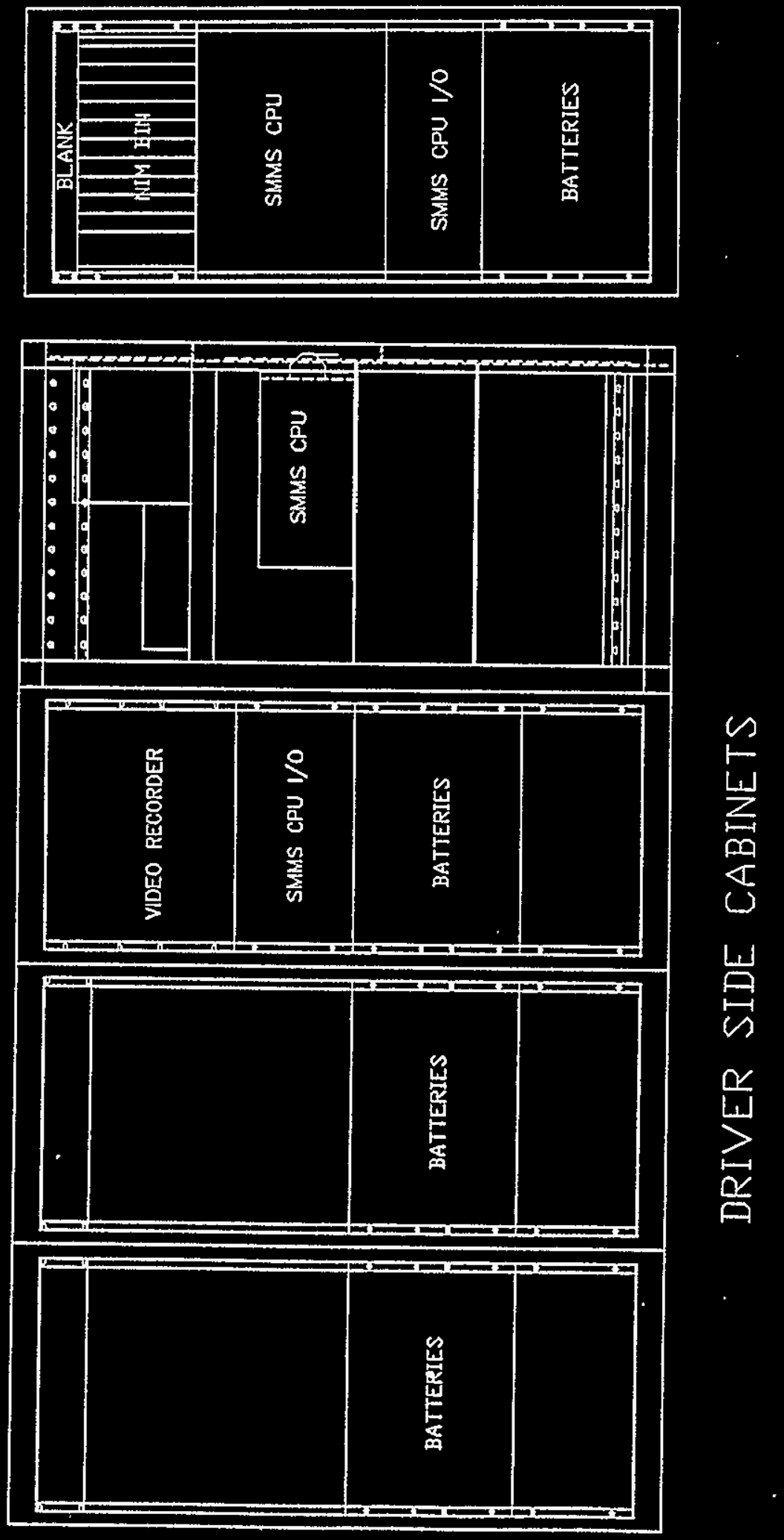
Figure 2-2. Layout of the Passenger Side Cabinets in the DAV.

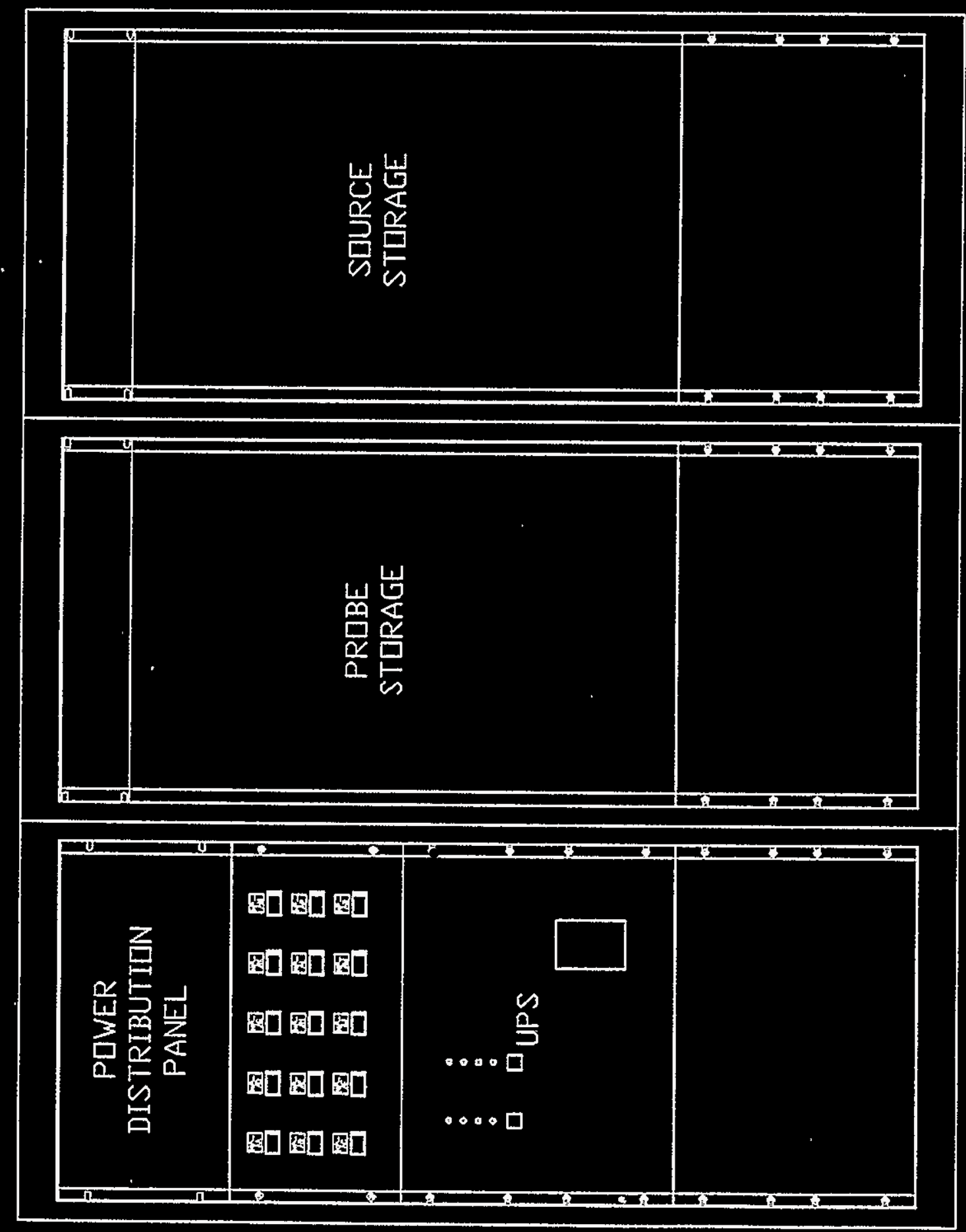

$\frac{n}{\frac{b}{\frac{b}{m}}}$

$\frac{\square}{\square}$

$\frac{1}{\omega}$
0
$z$
0
0
0
0 
WHC-SD-WM-OMM-024 REV 0

Figure 2-3. Operator Control Console in the DAV.

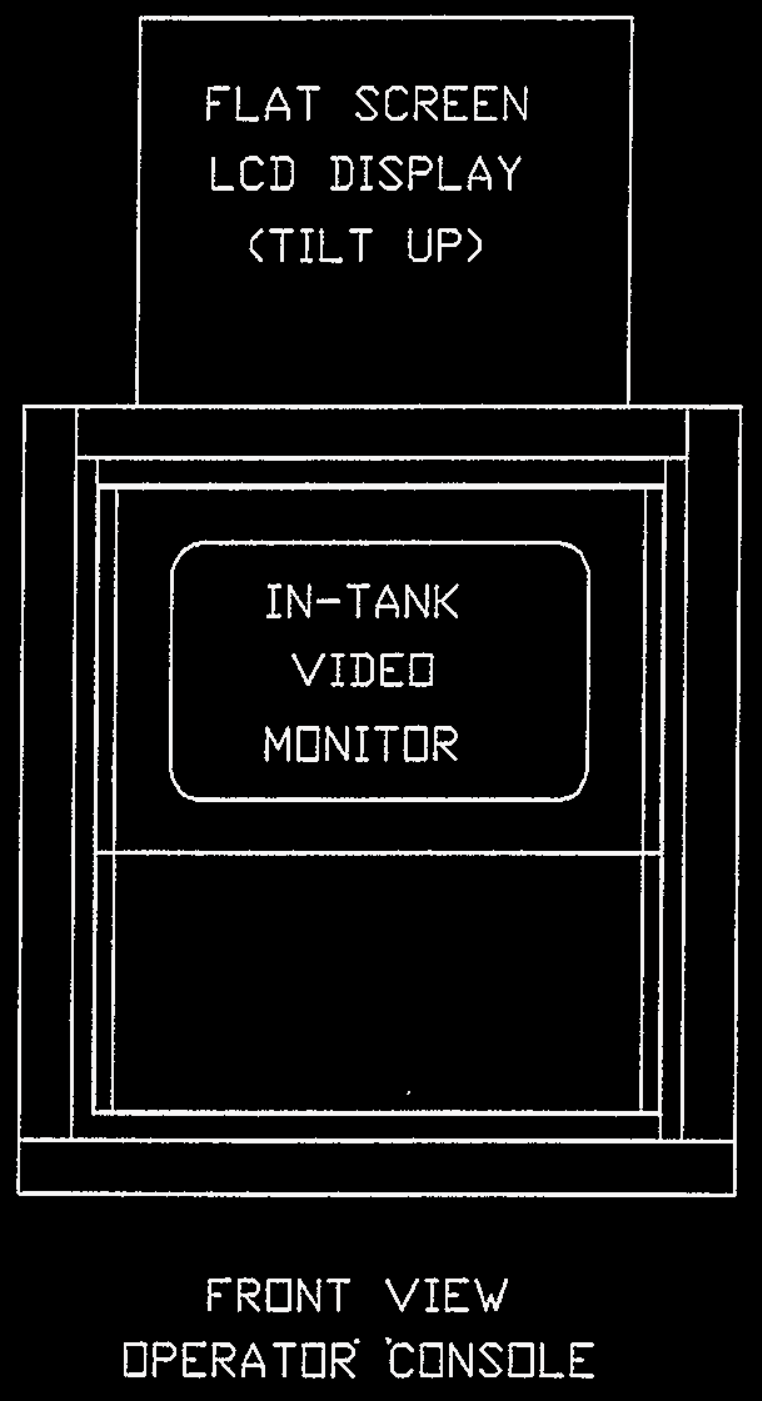


Figure 2-4. SMMS Software Front Panel Display.

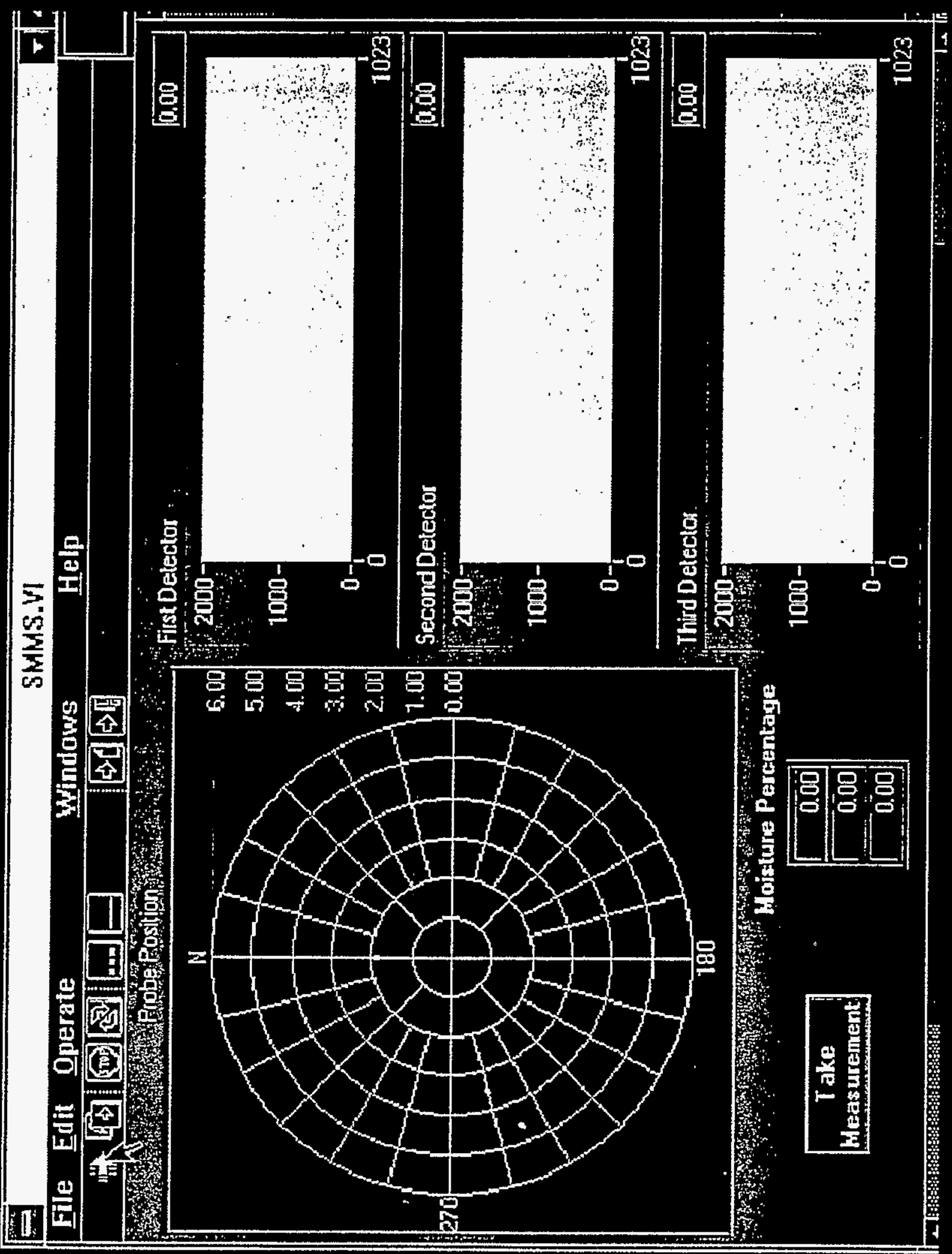


Figure 2-5. LOWMMS Software Front Panel Display.

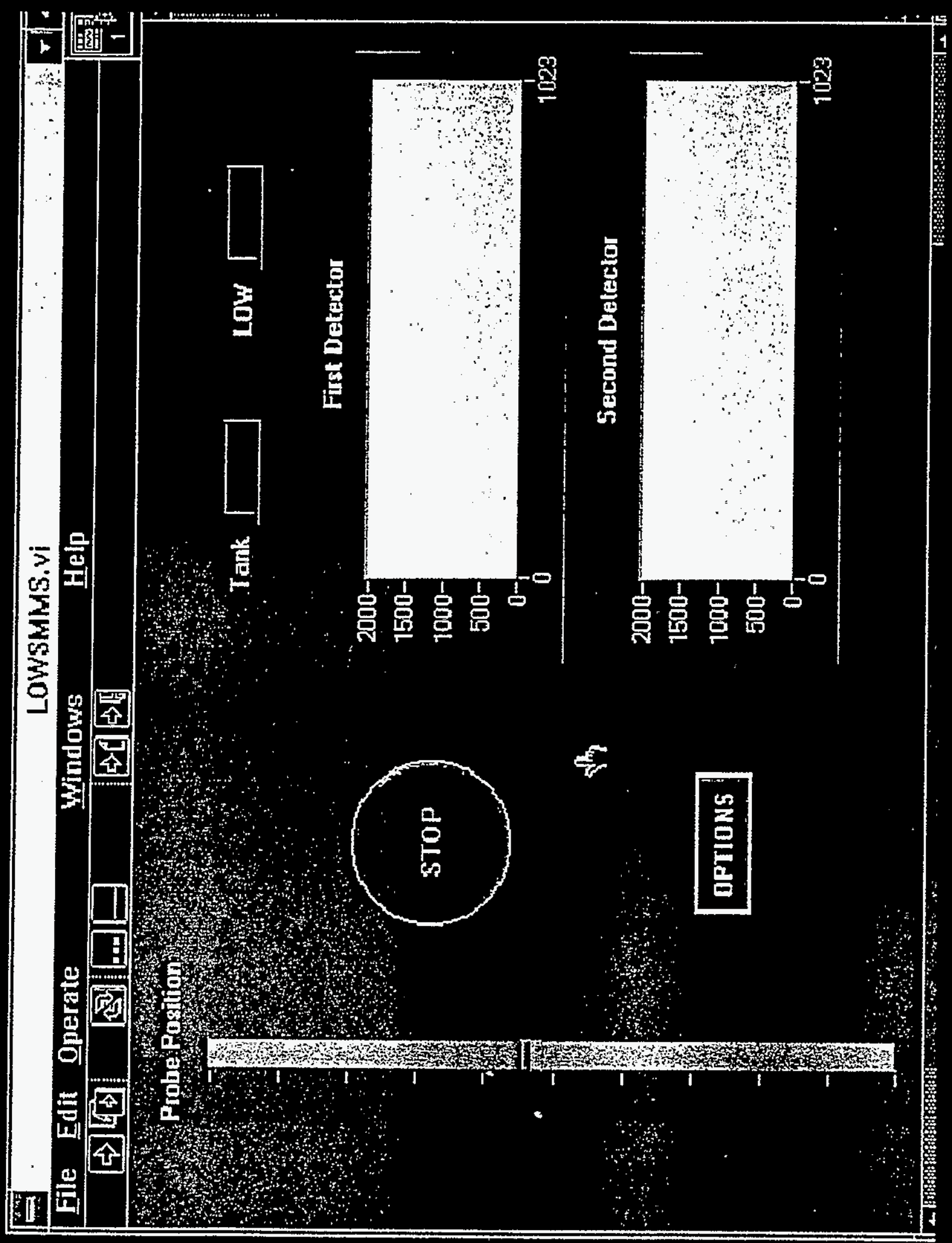


Figure 3-1. Combined Neutron and Gamma Dose from the SMMS Neutron Source.

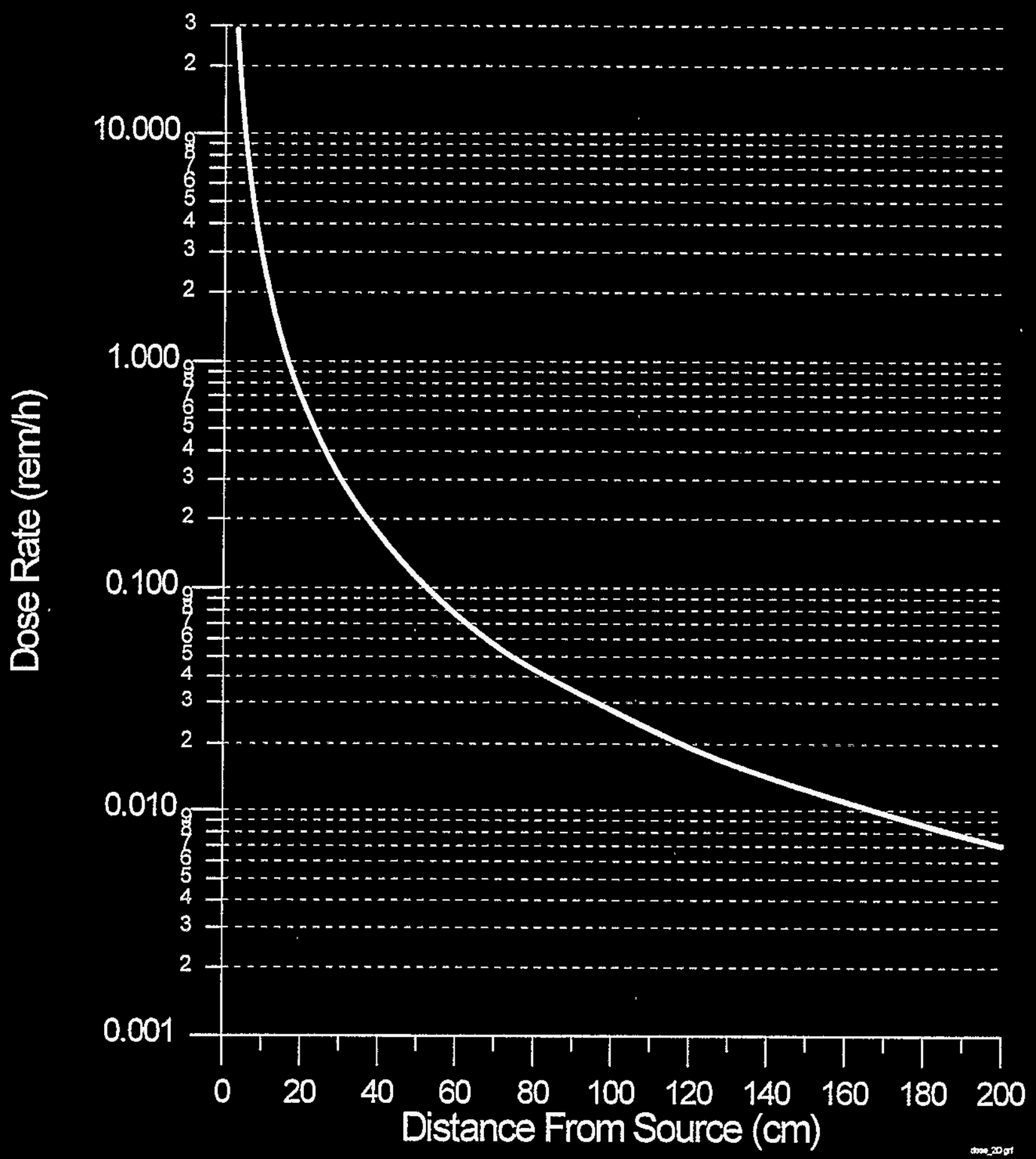


Figure 3-2. Combined Neutron and Gamma Dose from the LOWMMS Neutron Source.

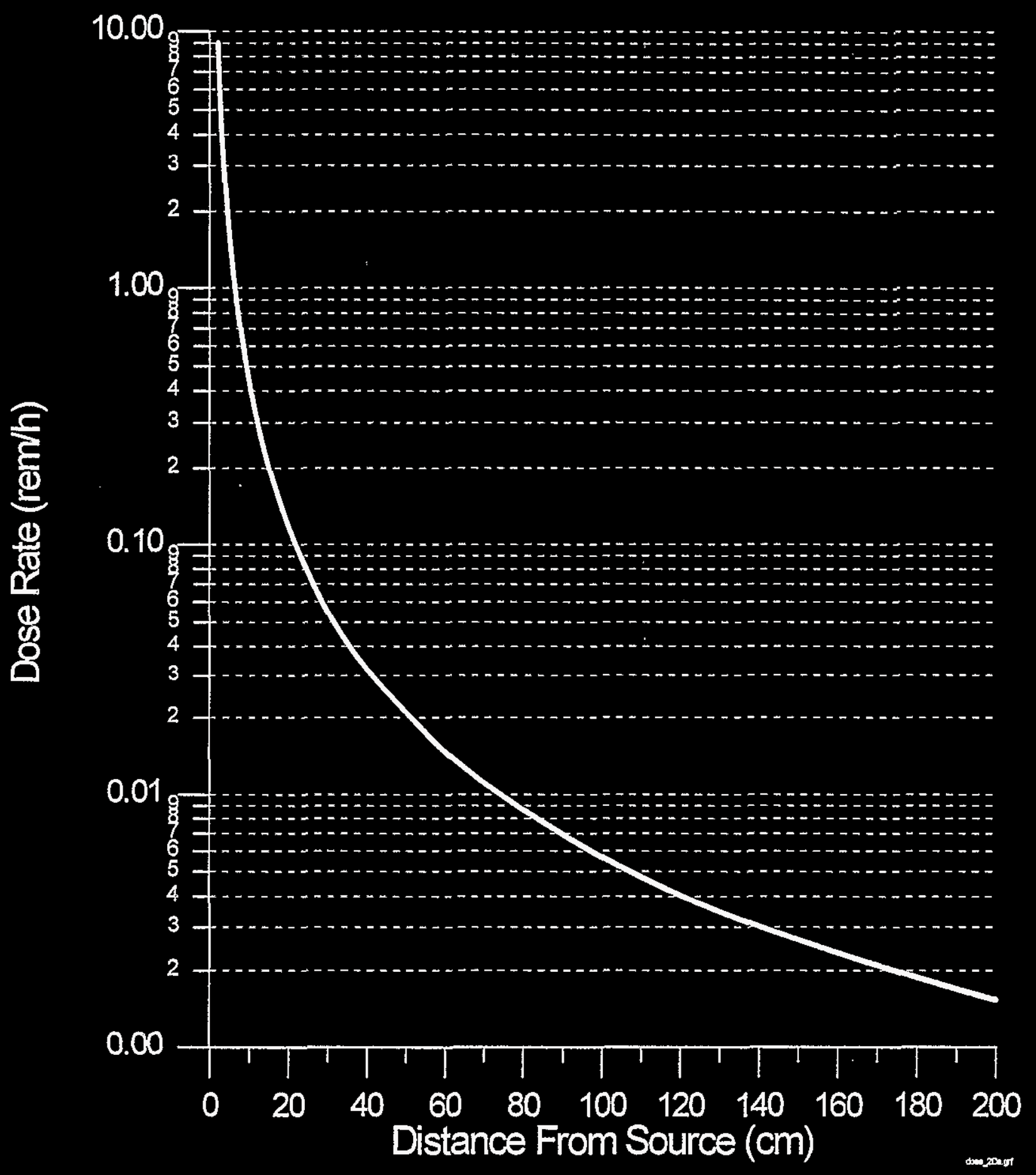


WHC-SD-WM-OMM-024 REV 0

Figure 5-1. Circuit Breaker Panel Layout.

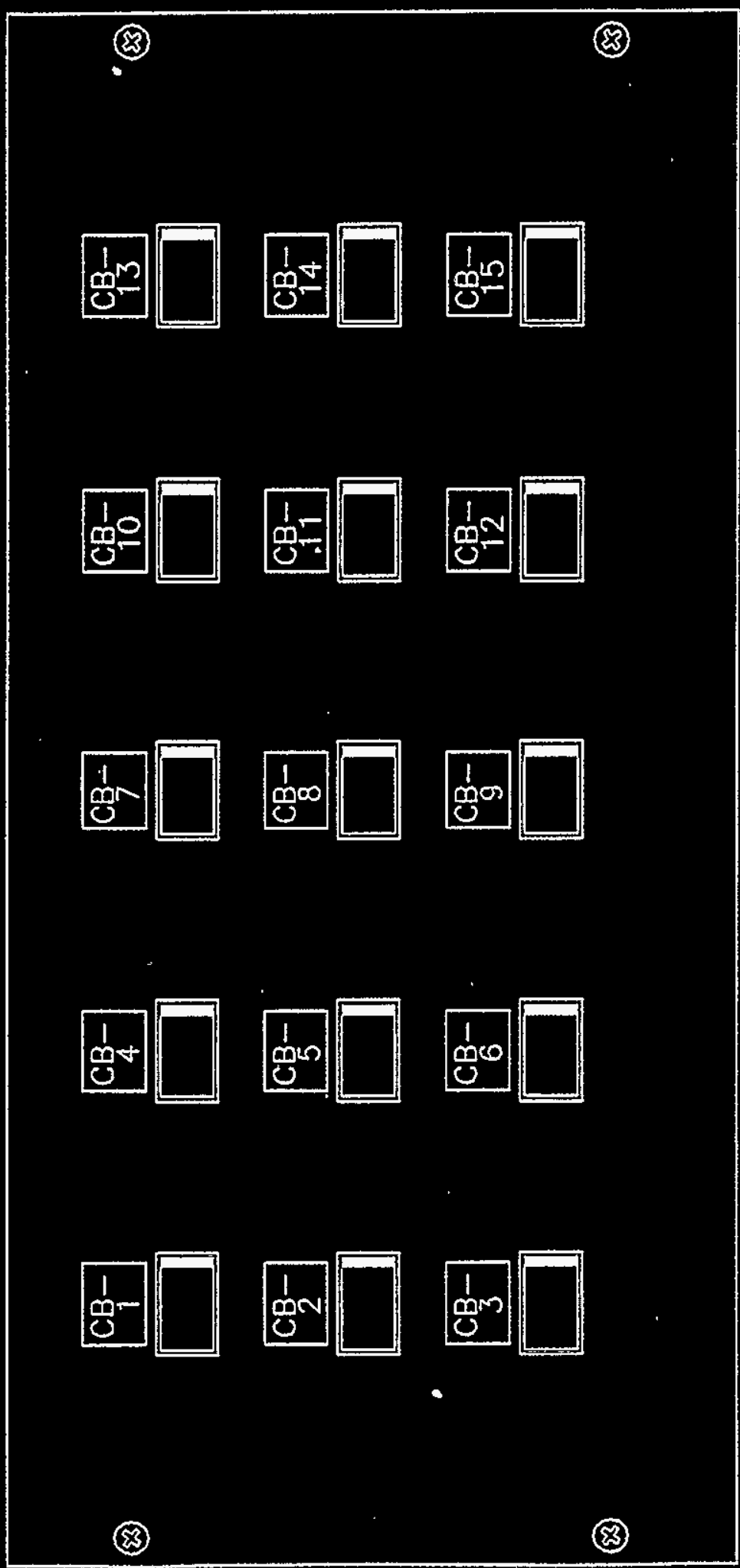


Figure 5-2. SMMS and LOWMMS Instrument Cable Connections.

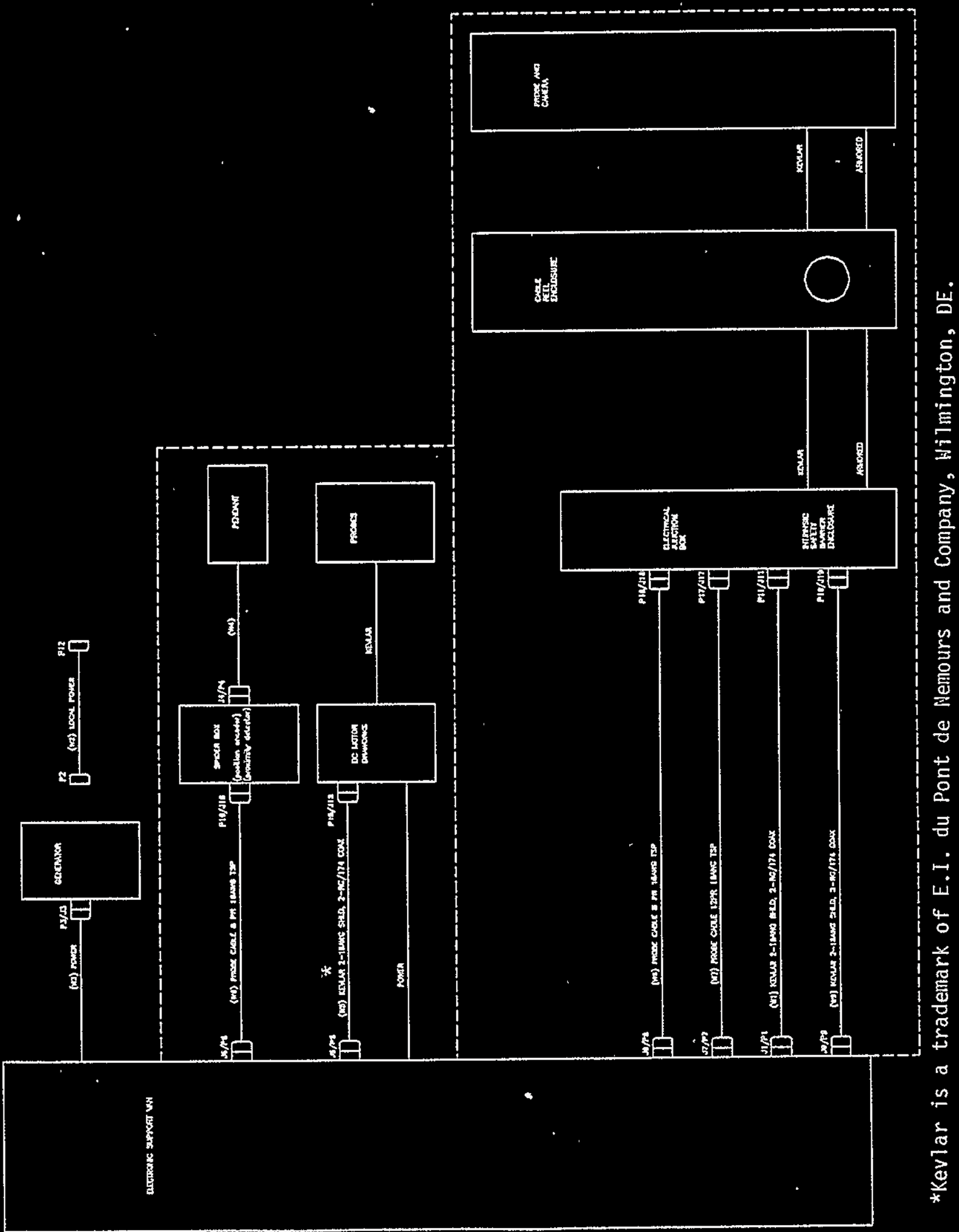


WHC-SD-WM-OMM-024 REV 0

Figure 5-3. SMMS Source Transfer Cask Arrangement.

[TBD-3 Figure 5-3. SMMS Source Transfer Cask Arrangement] 
WHC-SD-WM-OMM-024 REV 0

Figure 5-4. LOWMMS Source Transfer Cask Arrangement.

[TBD-4 Figure 5-4. LOWMMS Source Transfer Cask Arrangement] 
Figure 5-5. SMMS Decontamination System Block Diagram.

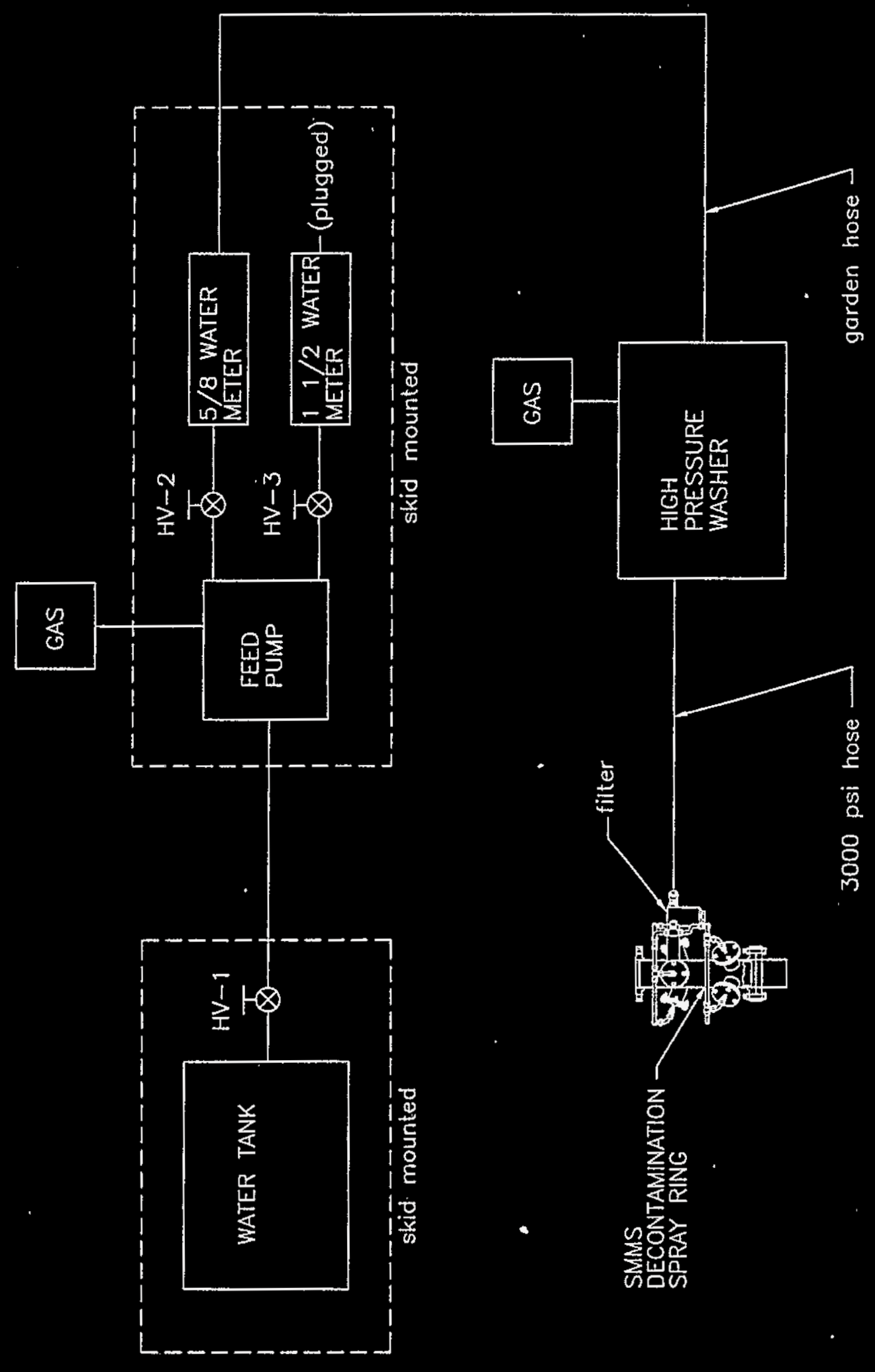




\section{DISTRIBUTION SHEET}

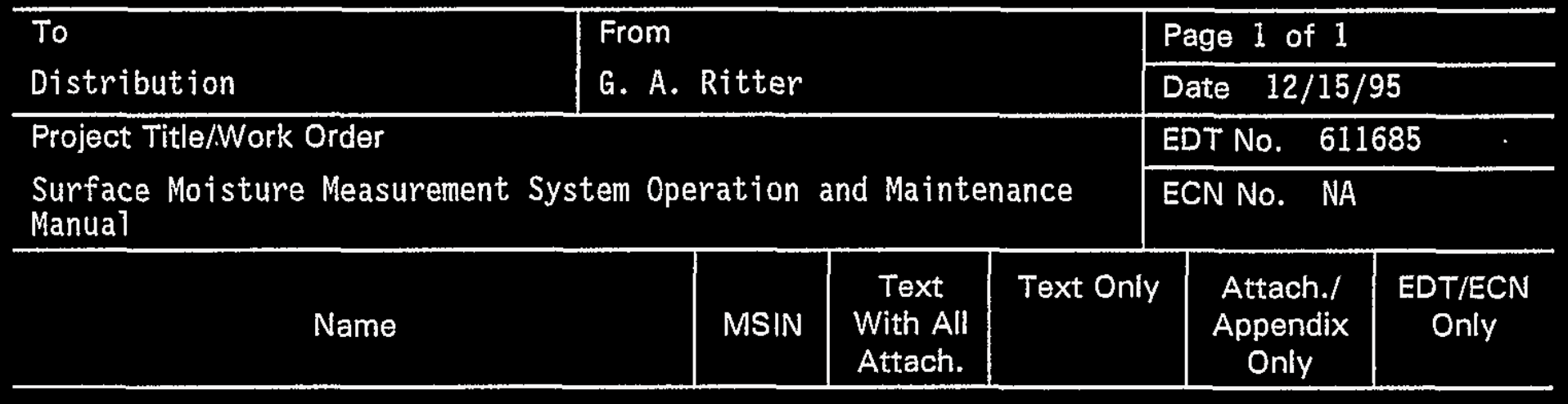

J. M. Bates

K. L. Bennett

D. R. Burstad

J. H. Busse 11

M. D. Clements

R. D. Crowe

P. R. Deichelbohrer

G. T. Dukelow

J. R. Ellis

M. Gimera

D. B. Graves

C. E. Hanson

W. J. Kennedy

L. S. Krogsrud

K7-15

N1-21

N2-50

L6-38

G2-02

HO-38

S7-12

S7-15

S7-07

L6-37

L6-37

H5-09

S7-03

J. W. Lentsch

R3-08

ST-15

M. L. McETroy

S1-07

R. E. Mendoza

R1-51

K. P. Mortensen

S7-05

K. E. Myers

G. A. Ritter

J. S. Schofield

57-03

$\mathrm{HO}-38$

57-12

R. R. Smith

N1-41

T. I. Stokes

G. F. Vargo Jr.

L6-37

H5- 09

A. E. Waltar

W. T. Watson

HO-32

Project Files

Central Files (orig + 2)

H0-38

H5-09

OSFI (z) 